\title{
A construção social de trajetórias de mando: \\ determinantes de gênero nos percursos ocupacionais"
}

\author{
Nadya Araujo Guimarães ** \\ Isabel Georges***
}

\begin{abstract}
Resumo
Neste texto analisamos as trajetórias ocupacionais e os discursos biográficos acerca da experiência do trabalho e do desemprego colhidos em dois levantamentos qualitativos. No primeiro, lidamos com os que cruzaram a porta de entrada do mercado de trabalho, entrevistando homens e mulheres ocupados em centrais de teleatendimento, que haviam experimentado a mobilidade ascendente em direção a funções de chefia. No segundo, contrafactual, analisamos relatos biográficos de um outro grupo de homens e mulheres, que haviam estado ocupados como chefes nos serviços e que, tendo perdido tais empregos, procuravam trabalho.
\end{abstract}

Palauras-chave: Trajetórias Ocupacionais, Representações, Chefias, Serviços, São Paulo.

\footnotetext{
* Recebido para publicação em abril de 2009, aceito em maio de 2009.

** Livre-Docente em Sociologia do Trabalho, Professora Titular do Departamento de Sociologia da Universidade de São Paulo, São Paulo.nadya@usp.br

*** Doutora em Sociologia, Pesquisadora do Institut de Recherche pour le Developpement, Paris, França e Pesquisadora Visitante na Universidade Estadual de Campinas, São Paulo. isabel.georges@wanadoo.fr
}

cadernos pagu (32), janeiro-junho de 2009:83-134. 
A construção social de trajetórias de mando

The Social Construction of Trajectories in Managerial Positions:

Gender Determinants in Occupational Careers

\begin{abstract}
The article compares two different sets of biographies and sociooccupational trajectories gathered in São Paulo metropolitan region to discuss the possible set of conditions that provide (or withhold) with resources those individuals submitted to high unemployment risk (correlated to processes of intense economic restructuring under fragile protection systems). The first data set encloses socio-occupational trajectories of men and women, in different moments of their lifecycle, who had been occupied as middle-range managers in service sectors, before losing their jobs as a result of firm restructuring processes. The second, taken as a contra-factual, provides socio-occupational trajectories of telemarketing operators, working at call centers; whilst most former middle-managers remained as long-term unemployed, those men and women, achieved to maintain their jobs even under precarious work conditions.
\end{abstract}

Key Words: Occupational Trajectories, Unemployment, Gender, Brazil, São Paulo. 
A reestruturação dos processos de trabalho não apenas modifica a natureza das relações de emprego prevalecentes nos locais de trabalho, como também altera as trajetórias individuais que se expressam nos mercados de trabalho. Entretanto, quando as mudanças nas estratégias das empresas têm lugar sob regimes de welfare caracterizados por baixos níveis de cobertura e por benefícios restritos, o risco da fragilização de vínculos se mostra particularmente elevado $e$ as trajetórias se tornam especialmente fragmentárias pelo efeito da recorrência no desemprego. ${ }^{1}$

Neste texto focalizaremos os percursos sócio-ocupacionais do ponto de vista dos indivíduos que os vivem e, em particular, da maneira como eles representam a experiência da obtenção e da perda de posições de mando. Comparando discursos biográficos individuais pretendemos trazer à luz possíveis mecanismos que atuaram no sentido de provê-los (ou privá-los) dos recursos para que fizessem face a uma conjuntura de alto risco de desemprego. Condição de sexo, posição no ciclo de vida e relações de gênero, por um lado; escolaridade e meio social de origem, por outro, mostraram-se importantes elementos na compreensão dos mecanismos e recursos mobilizados pelos entrevistados na construção das suas trajetórias. Além dessas características, as representações dos homens e mulheres sobre a família $e$ a situação de trabalho, que sustentam o desempenho dos papéis de gênero e de classe, ocuparam um lugar de destaque nos seus discursos sobre o trabalho, a posição de chefia e o desemprego.

Utilizaremos em nossa análise duas bases de discursos, obtidas de modo independente, mas articulado, e colhidas no mesmo momento de tempo. A primeira delas advém de um estudo sobre trajetórias sócio-ocupacionais de operadores $e$

1 Esping-Andersen (1999), Gallie e Paugam (2000) e Supiot (1999) estão entre os que refletiram recentemente sobre a pluralidade dos regimes de welfare. Freyssinet (1984), DiPrete e Krecker (1991), Demazière (1995), Demazière e Dubar (1997), Elias (1997) e Maruani (2002) documentaram esse fenômeno de fragilização de vínculos e reconfiguração das formas do desemprego para os casos norte-americano, francês e inglês. 
A construção social de trajetórias de mando

operadoras de tele-atendimento (telemarketing) em centros de chamada (call centers), nos quais desenvolvem atividades de informação, venda e assistência a clientes com base em novas tecnologias de informação. ${ }^{2}$ Como parte desse levantamento foram colhidas 32 entrevistas em profundidade sobre a trajetória profissional e a vida familiar de 15 homens e 17 mulheres, abordados em seus locais de trabalho entre março e novembro de 2002. Dos 32 entrevistados(as), 23 ocupavam posições subalternas, enquanto os 9 restantes exerciam posições de chefia (Georges, 2005 e 2005-a). Usando esse primeiro acervo de dados qualitativos buscaremos documentar as experiências $e$ representações associadas ao movimento de cruzar a porta de entrada do mundo dos empregos registrados, para engajar-se em uma ocupação em franca expansão no mercado metropolitano de trabalho. Várias dessas pessoas viviam a experiência da mobilidade social ascendente (se tomados os pontos de partida da geração dos seus pais), a qual não raro se traduzia numa mobilidade hierárquica em direção a funções de chefia.

$\mathrm{O}$ segundo conjunto de dados qualitativos, tomado aqui como um contrafactual, compreende trajetórias sócio-profissionais de homens e mulheres que encontráramos cruzando a porta de saída da atividade ocupacional regular. Tendo antes exercido funções de pequena e média gerência, também nos serviços, essas pessoas haviam perdido seus empregos no curso da intensa

2 Este material é parte de estudo mais amplo sobre carreiras nos serviços. Ele compreendeu levantamentos no Brasil e na França, comparando tanto "carreiras horizontais" (realizadas num mesmo nível hierárquico entre atividades diversas) de mulheres em empregos subalternos (no setor de tele-atendimento), quanto carreiras ascendentes de mulheres em uma profissão de prestígio recentemente feminizada (as engenheiras), também no setor de telecomunicações (Georges, 2005a). As observações e entrevistas do serviço de tele-atendimento em São Paulo foram realizadas no quadro da pesquisa de pós-doutorado financiada pela Fapesp e conduzida por uma das co-autoras (Georges, 2005), vinculada a projeto conduzido por outra das co-autoras (Guimarães e Leite, 2003). A coleta teve lugar em duas empresas de tele-atendimento e duas agências de emprego, na tentativa de melhor flagrar a diversidade das relações de trabalho no setor. 
reestruturação da economia paulista nos anos 1990, no bojo da qual se encolheram fortemente os escalões intermediários na hierarquia das firmas. No momento em que colhemos os seus relatos biográficos, esses indivíduos enfrentavam o desafio da sobrevivência e da continuidade da procura de trabalho. Os casos foram sorteados aleatoriamente a partir de uma amostra formada por cerca de sete mil pessoas, estatisticamente representativa dos desempregados da Região Metropolitana de São Paulo, investigados por meio de um survey domiciliar sobre transições ocupacionais. ${ }^{3}$ Duas sessões de entrevista em profundidade foram realizadas com cada um dos 12 ex-chefes sorteados (sete homens e cinco mulheres); a primeira delas teve lugar em 2002 e a segunda em 2003 (Guimarães et alii, 2003).

$\mathrm{O}$ nosso argumento se organizará em duas seções. $\mathrm{Na}$ primeira, situaremos o contexto que vamos estudar, especificando as características do nosso objeto empírico; isto nos permitirá introduzir à consideração do leitor a dinâmica estrutural que estava em jogo na Região Metropolitana de São Paulo e que, nesse sentido, provia os graus de liberdade para a organização das escolhas dos sujeitos. Na segunda seção, nos debruçaremos sobre os dados qualitativos obtidos através dos dois levantamentos por entrevistas em profundidade com chefias médias, ocupados e desempregados; buscaremos ilustrar como tais percursos de

${ }^{3}$ Esta pesquisa, coordenada por uma das co-autoras, investigou as transições no mercado de trabalho (entre situações de ocupação, desemprego e inatividade) daqueles indivíduos com 16 anos e mais, residentes na Região Metropolitana de São Paulo e tomou como referência o período compreendido entre 1994 (ano do Plano Real) e 2001 (momento do trabalho de campo). Um questionário suplementar à Pesquisa de Emprego e Desemprego da Fundação SEADE foi levado a campo durante nove meses, entre abril e dezembro de 2001. Cerca de 27 mil domicílios foram pesquisados, com 57 mil casos levantados, sendo 34 mil ocupados, sete mil desempregados e 16 mil inativos no momento da coleta. Entre 2002 e 2004, cerca de 70 indivíduos foram sorteados neste banco de casos para uma segunda fase da pesquisa; nela, duas entrevistas biográficas em profundidade foram realizadas, no intervalo de um ano. Os casos aqui analisados são parte deste grupo. Detalhes em Guimarães et alii, 2003. 
A construção social de trajetórias de mando

passagem pela experiência de posições de mando foram vividos pelos indivíduos e como as relações de gênero são decisivas para entendermos as suas construções discursivas com respeito a tal experiência. Assim fazendo, pretendemos argüir como essas micro-decisões, expressas nos discursos sobre o trabalho, sobre a chefia e sobre o desemprego, vão, em última instancia, construir a operação cotidiana do mercado de trabalho, se o focalizarmos pelo ângulo dos que nele demandam trabalho.

\section{O contexto empírico e seu interesse analítico}

Que dizer da organização do mercado de trabalho da Região Metropolitana de São Paulo nos anos recentes? Alguns aspectos são particularmente interessantes como pontos de partida para a nossa reflexão. Em primeiro lugar, o incremento persistente e acelerado da taxa de desemprego total, que dobrou no curso dos anos 90; de fato, tendo iniciado a década no patamar de $10 \%$, ela chegou a alcançar o valor inédito de $20 \%$ em 1999, recuando para $18 \%$ no momento em que iniciávamos o trabalho de campo, em 2001. Em segundo lugar, o aumento igualmente acelerado $e$ persistente do tempo de procura de trabalho, que triplicou no período que antecede à coleta de dados, passando de 15 semanas em 1990 para 45 semanas em 2001 (Guimarães, no prelo).

Ademais, há que ter em conta que tudo isso tem lugar num contexto de frágil institucionalização do desemprego, sob um sistema de proteção fortemente seletivo, dados os critérios de elegibilidade do seguro-desemprego que, além de recente, tem tido valores reduzidos e vigência que fica muito aquém do tempo de permanência no desemprego. Por isso mesmo, não é de espantar que, nesse período, a forma do desemprego oculto (tanto pelo trabalho considerado precário, como pelo desalento) tenha sido aquela que cresceu a um ritmo mais acentuado. Conquanto o desemprego aberto também tivesse manifestado tendência significativa ao aumento, era impossível manter-se duradouramente desempregado, dedicando-se apenas à procura 
de trabalho num regime de welfare como o que se instituiu no Brasil.

Mas a flexibilidade numérica não é um traço restrito seja ao mercado de São Paulo, seja a essa década. Importante literatura já se havia encarregado de chamar a atenção para a sua importância enquanto elemento regulador do funcionamento do mercado de trabalho no Brasil em décadas anteriores (Amadeo et alii, 1993 e 1994; Urani, 1995; Dedecca e Brandão, 1993; Dedecca e Montagner, 1993). Entretanto, alguns novos aspectos atraíram os analistas que se debruçaram sobre as novas tendências dos anos 1990. O principal deles apontava para a necessidade de entender quão efetivo estava sendo o crescente desemprego no sentido de produzir uma redistribuição das oportunidades de trabalho, agora não apenas nos contextos de crise, mas ao longo de toda a década. Tal redistribuição deveria ter conseqüências do ponto de vista das trajetórias ocupacionais dos indivíduos, e esse rapidamente se tornou o foco de uma nova leva de trabalhos (Guimarães et alii, 2003; Comin, 2003; Guimarães, 2006; Brandão et alii, 2006).

À luz dessas análises, duas outras características se destacaram como conferindo especificidade ao funcionamento do mercado paulistano de trabalho. Por um lado, embora aumentassem a desocupação e o tempo de procura de trabalho no mercado metropolitano, estávamos longe de encontrar aqui o fenômeno do "desemprego de longa duração" que vem assolando os países capitalistas avançados, notadamente naqueles onde um regime inclusivo de welfare se consolidara, protegendo os desempregados e apoiando-os em seus esforços de procura de um novo trabalho. Aqui, ao contrário, é a figura do "desemprego recorrente", livre de proteção substancial e de longa duração, aquela figura que dá sentido à dinâmica das transições ocupacionais. Seu resultado? Transições ainda mais intensas e trajetórias fragmentadas (Brandão et alii, 2006).

Uma outra característica importante diz respeito à recorrência do movimento de entrada e saída do mercado de 
A construção social de trajetórias de mando

trabalho, isto é, às transições entre atividade $e$ inatividade econômica. Estudos recentes têm documentado que o modelo de transição no mercado paulistano de trabalho contempla tanto a mobilidade que se faz entre situações de ocupação e desemprego como a mobilidade entre situações de atividade $e$ inatividade (Guimarães et alii, 2003; Guimarães 2005; Brandão et alii, 2006); ou seja, tanto a mobilidade que ocorre nos limites internos ao mercado (tal como analiticamente costumamos entendê-lo), quanto a mobilidade que ocorre para além desses limites, assumindo a forma de um trânsito entre ocupação (ou desemprego) e inatividade. Desse modo, as transições no mercado da Região Metropolitana de São Paulo ocorrem corriqueiramente entre as três situações possíveis face à atividade econômica (ocupação, desemprego e inatividade), e não apenas entre as duas situações que tipificariam os movimentos dos que formam a força de trabalho (isto é, entre as situações de ocupação e desemprego).

Sabemos que o alto risco de desemprego atinge de modo desigual os indivíduos. Assim, tanto quanto nos mercados de trabalho dos países capitalistas centrais, os desempregados são predominantemente jovens que tentam seu primeiro emprego; mulheres que buscam retornar ao mercado depois de uma carreira reprodutiva, ou que nele procuram se manter engajadas conciliando papéis ocupacionais e papéis familiares; trabalhadores manuais, que por longo tempo estiveram ocupados na indústria $e$ que agora enfrentam os efeitos da intensa reestruturação produtiva que nela tem lugar; além de chefias médias, atingidas pelo movimento de redução de níveis hierárquicos, de "achatamento" das estruturas de comando, que levou de roldão, e com rapidez impressionante, justamente essas camadas intermediárias do gerenciamento.

Neste texto escolhemos focalizar um grupo particular: o daqueles indivíduos que haviam estado ocupados em funções de média gerência no setor de serviços. Fixar a atenção nas transições ocupacionais daqueles que não apenas haviam 
conseguido obter um emprego, mas que nele lograram ascender a posições de poder, nos pareceu interessante por permitir analisar trajetórias e biografias num grupo para o qual a mobilidade fora uma possibilidade real, explorando perfis e condições sob as quais o movimento nas carreiras se tornara possível. Restringimos, entretanto, a nossa observação à pequena e média gerência, de sorte a refletirmos melhor sobre os efeitos desse momento de intensa reestruturação dos processos e do mercado de trabalho sobre um contingente numericamente importante da força de trabalho na Região Metropolitana de São Paulo. Não seria carente de interesse analítico pensar este movimento no que concerne à alta gerência ${ }^{4}$; entretanto, se os seus percursos de mobilidade poderiam ser mais longos, eles nem de longe seriam representativos das possibilidades da ascensão e dos riscos postos pelas transições ocupacionais num mercado de trabalho como o brasileiro em geral e paulistano em especial.

E por que escolhemos o setor de serviços? Em primeiro lugar, pelo seu importante papel na criação de oportunidades ocupacionais. Quando a reestruturação econômica e a abertura internacional se aprofundaram nos anos 1990, não vimos, em São Paulo, um movimento de desindustrialização, como em algum momento se chegou a pensar. Ao contrário, novos investimentos produtivos alteraram fortemente o ambiente interno das firmas $e$ seus padrões de competição e de associação, consolidando ao tempo em que renovavam o perfil dos "brownfields" manufatureiros paulistanos. Mas é certo que a contra-face dessa mudança foi o forte encolhimento dos empregos industriais, que conviveu com uma intensa redivisão inter-setorial do trabalho, responsável pelo significativo crescimento da ocupação nos serviços que teve lugar no período (Cardoso, 2000; Comin, 2003; Guimarães, 2004 e 2004a).

\footnotetext{
4 Ao modo dos inovadores estudos conduzidos anteriormente por Grün (1992 e 1999), por exemplo.
} 
A construção social de trajetórias de mando

Entretanto, o setor de serviços nos importa por uma outra razão: a sua permeabilidade ao emprego de mulheres, uma tendência nacional que se manifesta com bastante força, nos anos 2000, em São Paulo (Guimarães e Leite, 2003). Essa característica facilita a nossa análise sobre diferenças de gênero nas trajetórias e biografias ocupacionais. Isso porque, na medida em que há um espaço (também) aberto às mulheres, essas ocupações (como discutiremos em seguida) podem se tornar alvos de mobilidade para aquelas que não apenas queiram se manter no mercado de trabalho, mas que pretendam conciliar papéis ocupacionais e de gênero sem abrir mão de uma aspiração ao ingresso e promoção em suas carreiras. ${ }^{5}$

Num tal contexto, os padrões de transição ocupacional daqueles indivíduos que ocupavam funções de pequena e média gerência na região metropolitana de São Paulo tornam-se um interessante objeto de pesquisa. Como os atingia o contexto paulistano, marcado por transições intensas e trajetórias fragmentadas? Em estudo anterior (Georges e Guimarães, 2005), quando analisamos as trajetórias ocupacionais dos indivíduos economicamente ativos entre 1994 (Plano Real) e 2001 (momento do levantamento de campo) nos foi possível reconhecer ao menos duas grandes linhas de clivagem a diferenciá-los. Primeira delas,

5 Dentro dos serviços, o foco no ramo dos serviços de tele-atendimento apresenta um interesse adicional. Trata-se de um setor moderno, assentado em tecnologia de ponta e que se constituía numa das mais importantes avenidas abertas no que tange a oportunidades de trabalho. Dados da Associação Brasileira de Telemarketing (ABT) indicavam que, em 2002, o setor crescia a uma taxa anual de $30 \%$. Mas, e voltando à nossa perspectiva de gênero, o teleatendimento era também um segmento da atividade onde o tipo de recrutamento e a natureza do trabalho privilegiavam a escolaridade formal, requerendo-se no mínimo o segundo grau completo; isto valorizava o uso de saberes formais, adquiridos na esfera pública, no que as mulheres paulistanas estavam em clara vantagem (Georges, 2005b). Entretanto, num mercado caracterizado por transições intensas, também neste setor a taxa de rotatividade era importante (chegando a alcançar $30 \%$ ao ano) e a mobilidade estava restrita a um punhado de posições, já que 80 a $90 \%$ dos trabalhadores estavam em posições subalternas (Id. ib.). 
uma linha de natureza social, que particulariza os gerentes, mesmo os pequenos e médios, frente à realidade da maioria dos que transitam no mercado paulistano de trabalho: sua mobilidade entre situações nesse mercado parece de algum modo protegida por sua posição social; ou seja, três quartos deles fazem, no período, trajetos nos quais a marca primeira é dada por conseguirem se manter regularmente ocupados, e não pela recorrência do desemprego, como ocorre para a maioria dos paulistanos. Entre os paulistanos, ironicamente, a mesma fração, ou seja, três quartos em média, percorre caminhos opostos, marcados recorrentemente pelo desemprego (Guimarães, 2005).

Mas quando procuramos identificar quem são aqueles que apresentam esses tipos bem-sucedidos de trajetória, vemos que são homens, brancos, chefes-de-família, e provenientes de meios sociais seletos que lhes propiciaram uma escolarização elevada cujo retorno lhes chega agora. Assim, manter-se no mercado, duradouramente ocupado e com remuneração condigna, é um resultado que traz marcas indeléveis, associadas à condição de gênero, racial, geracional e ao meio de origem.

E quem são aqueles gerentes que não possuem os signos que a seletividade do mercado reconhece como capazes de protegê-los da incerteza? São eles os que fazem as trajetórias de risco, mal-sucedidas, marcadas por transições muito intensas, por passagens recorrentes pelo desemprego, por eventos de entrada $e$ saída do mercado de trabalho. Eles são homens, negros, e mulheres, brancas e negras; uns e outros com escolarização precária. A análise estatística que realizamos anteriormente nos permitiu, assim, descortinar os limites estruturais dentro dos quais se produziam esses diferentes tipos de trajetos.

Entretanto, tal análise era silente com respeito a aspectos analíticos centrais, a saber: Como os indivíduos representam os limites $e$ as possibilidades do mercado com o qual se defrontam? Que mecanismos são por eles mobilizados para fazer face a tais constrangimentos estruturais? Como, para enfrentar um mercado adverso, desenvolvem estratégias e tomam iniciativas a partir de 
A construção social de trajetórias de mando

suas características pessoais e singulares? ${ }^{6}$ Quanto do anterior se revela em seus discursos acerca da experiência do trabalho e do desemprego? Qual o significado de ter e perder (ou de não ter tido e vir a obter) uma posição de mando? A isso nos dedicaremos doravante.

\section{A construção social das trajetórias sócio-profissionais: entradas e saídas}

Vimos, antes, que são variados os tipos de trajetória dos trabalhadores ocupados em funções de pequena e média gerência no mercado de trabalho paulistano. São múltiplos os movimentos de transição ocupacional por eles realizados. Tal análise quantitativa sugere a existência de importantes macrocondicionantes (de natureza estrutural) desses percursos. Posição social, condição de gênero e de raça, posição no ciclo de vida são fatores estreitamente relacionados aos tipos de trajetória. Eles estabelecem, por assim dizer, os graus de liberdade dentro dos quais as escolhas individuais têm lugar, diferenciando os indivíduos por sua posição na estrutura social e tornando fortemente seletivas as chances de fazer-se um percurso mais virtuoso ou mais precário no mercado de trabalho.

Entretanto, uma segunda ordem de indagações merece ser perseguida. Ela diz respeito aos mecanismos que operam cotidiana e concretamente na produção dessas trajetórias, às micro-condições a partir das quais se produzem tais padrões. Ela valoriza o processo através do qual se formam as escolhas dos indivíduos, os valores que lhes servem de orientação para a

6 Lautier e Marques Pereira (1994) discutiram de maneira instigante o tema das "estratégias" ocupacionais em seus elos com outros tipos de estratégias (residenciais, afetivas e matrimoniais). Os autores argúem a importância das representações dos indivíduos a respeito do mercado de trabalho e das suas possibilidades de inserção para a elaboração de tais estratégias, inclusive entre trabalhadores(as) pouco qualificados(as) e/ou com uma inserção precária no mercado de trabalho. Eles sugerem que tais estratégias atuam como mecanismos de regulação alternativa do mercado de trabalho. 
tomada de decisões $e$ as representações que os mesmos tecem acerca do trajeto sócio-profissional que efetua(ra)m.

Com Hughes (1937), acreditamos no valor heurístico de um estudo das carreiras que diferencie suas dimensões "objetiva" $e$ "subjetiva": a primeira correspondendo a um conjunto "factual" de posições e situações de trabalho, enquanto a segunda referindo-se notadamente à formação $e$ às mudanças de perspectiva do indivíduo com respeito a sua própria trajetória.

Mas o leitor pode indagar qual o interesse analítico de se pensar a construção das trajetórias pelo ângulo das representações expressas nos discursos dos indivíduos? Estamos convictas de que várias são as vantagens adicionadas pela adoção desse segundo tipo de enfoque. Primeira, ele nos faculta levar o esforço por construir a explicação sociológica até o ponto em que ela se torna mais próxima do movimento concreto dos atores singulares, captando o sentido que os mesmos conferem às suas condutas no mercado de trabalho, de modo a compreendermos os motivos que animam as suas ações e evidenciarmos que, se a dinâmica estrutural estabelece parâmetros para as escolhas, ela apenas abre o amplo leque de possibilidades de conduta. ${ }^{7}$ É o protagonismo dos sujeitos que dá sentido, interpretando, às oportunidades estruturais; ao fazê-lo, evidencia-se a capacidade individual de construir cotidianamente a realidade ao agir, aquilo que no jargão disciplinar costumamos denominar de agency. O estudo das configurações dos mercados de trabalho tem muito a ganhar com abordagens voltadas a entender a sua construção cotidiana e que levam o desafio da explicação sociológica até o coração da relação entre estrutura e ação (Giddens, 1984; Knorr-Cetina e Cicourel, 1981, entre outros).

Uma segunda ordem de aspectos, já mais específicos, nos parece também sustentar o interesse pelo enfoque qualitativo que desenvolveremos a seguir. Diante de idênticos constrangimentos

\footnotetext{
7 Seguindo no diálogo com Hughes, é evidente que aqui pensamos, e com ele,
} nas "bifurcações" a que estão sujeitos os cursos das "carreiras" (Hughes, 1937). 
A construção social de trajetórias de mando

estruturais, os indivíduos, em sua singularidade, compreendemnos e estabelecem para si alvos que lhes são próprios, ainda quando compartam características que os localizariam em espaços de proximidade da estrutura social.

Assim, para chegarmos mais perto do tipo de interesse que nos move, diríamos, por exemplo, que ampla literatura aponta a diversidade das chances de homens e mulheres no que concerne à mobilidade nas carreiras em direção a posições de mando. Padrões "masculinos" e "femininos" em carreiras sócioprofissionais são expectativas analíticas correntes. Entretanto, se compararmos relatos de diferentes mulheres, regularmente ocupadas, inseridas em carreiras que lhes abrem horizontes de mobilidade na hierarquia ocupacional, veremos que variam os significados que cada uma delas confere às condições em que competem, tanto quanto variam as apreciações que formulam sobre as decisões tomadas no curso dos seus trajetos. Algumas representações, em particular sobre a família e as relações sociais de gênero, mostram-se decisivas na construção de suas trajetórias, isto é, na transformação de um curso provável, dado por uma certa inscrição estrutural, em curso efetivo, resultado das suas interpretações e da sua ação. ${ }^{8}$

Por certo, e essa é uma terceira ordem de argumentação, podemos encontrar recorrências nas construções discursivas individuais. Elas nos permitem isolar formulações densas, que tipificam maneiras de conferir sentido e de orientar a conduta no mercado. Alguns tipos de discurso sustentam formas de ação dirigidas a manter-se e progredir no trabalho; outros justificam, para o próprio sujeito, uma avaliação que o move a sair do mercado, ou quando menos a sair da competição pelos postos de mando, mesmo se esse mando se exerce em níveis intermediários das estruturas organizacionais de poder.

8 Recentes resultados de pesquisa sobre os meios populares em São Paulo, por exemplo, mostraram que são, sobretudo, as representações acerca da família, e o seu possível papel de rede solidária, que mudam o rumo das trajetórias de trabalhadores na metrópole (Cabanes, 2002). 
Tal é o tipo de esforço interpretativo que nos interessa empreender. Para tanto, analisaremos trajetórias sócioprofissionais de dois grupos. No primeiro deles estão homens $e$ mulheres regularmente ocupados(a)s em centrais de chamadas, no setor de tele-atendimento, da região metropolitana de São Paulo; vário(a)s dentre ele(a)s haviam experimentado a mobilidade ascendente em direção a posições de mando. No segundo grupo, ao qual recorreremos como um contrafactual, estão homens $e$ mulheres atualmente desempregados(as), mas que, antes de terem sido demitidos, ocuparam cargos de chefia, também nos serviços e nessa mesma metrópole; privados de tais empregos, procuravam trabalho. O primeiro grupo reúne, então, um conjunto de trajetórias de pessoas orientadas para a entrada e a ascensão na vida profissional. Já o segundo, revela um grupo de percursos que expunham os sujeitos aos riscos da porta de saída, seja do mando, seja da ocupação, seja até (para alguns deles) do próprio mercado de trabalho em direção à inatividade. Suas trajetórias, tal como uns e outros as recontaram, bem como as construções discursivas às quais recorreram para dar sentido a um certo encadeamento cronológico de eventos profissionais vividos serão o nosso material para reflexão.

Os casos a que nos reportaremos doravante são uma pequena e seleta parcela dentre os que foram colhidos em campo. Eles foram retirados de um conjunto maior de entrevistas com indivíduos que atendiam a configurações inicias de alguns gruposalvo, tipificados por sua relevância analítica, uma vez que partilhavam traços comuns em termos de origem social, de sexo, de idade, de posição no ciclo de vida e de cor. Eles foram deliberadamente escolhidos pela riqueza das trajetórias narradas e pela densidade dos seus discursos, o que, a nossos olhos, os torna capazes de reunir e integrar elementos de significação dispersos em outras narrativas, desafiando, assim, a nossa intuição interpretativa. Ao permitirem avançar na compreensão dos mecanismos que operam a construção de suas trajetórias, nos oferecem os elementos para interpretar padrões distintos, uma 
A construção social de trajetórias de mando

gama mais ampla de possibilidades de micro-construção de percursos.

A nossa atenção doravante estará voltada para entender como se produz a ação desses indivíduos a partir das inúmeras e sucessivas micro-decisões que eles cotidianamente tomam, $e$ como a interpretação da sua situação vis-à-vis o mercado de trabalho é um elemento decisivo para a conduta que produz, ao final, um dado trajeto sócio-profissional.

2.1. Entradas: caminhos de gênero, na entrada, permanência e progressão nos serviços de tele-atendimento

É possível demonstrar que as representações dos indivíduos sobre as relações sociais de gênero e sobre a sua situação de trabalho influenciam o tipo de dinâmica que imprimem a suas trajetórias? Vejamos o que nos ilustra o conjunto dos casos escolhidos nessa seção.

Eles têm algumas características em comum. São pessoas que trabalham nos serviços de tele-atendimento. Ocupam, atualmente, uma posição de mando (coordenadora, supervisora), já ocuparam uma posição de mando (gerente), ou almejam uma mobilidade sustentada no acúmulo de vantagens sociais vinculadas ao emprego. Todos provêm de uma origem social relativamente baixa, com uma diferença fundamental: alguns dispõem de uma família de origem melhor estabelecida (com pais trabalhadores qualificados estáveis), enquanto outros não (filhos de empregada doméstica, órfãos). Mas há outros aspectos que os diferenciam, além deste. São homens e mulheres deliberadamente escolhidos por sua variada origem étnica, por estarem em momentos diferentes do ciclo de vida e por distinta idade biológica.

Para melhor sistematizar, diferenciamos dois tipos principais de mobilidade ascendente, que chamaremos "mobilidade social" e "mobilidade profissional". A primeira é uma forma de mobilidade que se caracteriza pela ascensão social facilmente 
perceptível (para o observador) e percebida (pelo próprio sujeito) através da comparação entre a sua situação atual em relação ao trabalho $e$ as características do seu meio social de origem, comumente expressas na ocupação dos pais; esses indivíduos ilustram casos onde ocorre uma mobilidade inter-geracional, geralmente associada ao progresso facultado pelos estudos, que os localiza em uma rede intra-geracional. Já o que chamamos de mobilidade profissional se manifesta por uma ascensão expressa seja nos avanços que se dão nos mercados internos de trabalho, galgando posições em carreiras formalmente estruturadas, seja progredindo no mercado externo pela via da mobilidade em direção a empregos com maiores vantagens salariais e/ou mais direitos (como estabilidade, salário, possibilidades de carreira); no ramo dos serviços de tele-atendimento esses novos empregos geralmente se localizam a montante da cadeia da divisão do trabalho, o que os faz passar, por exemplo, de uma empresa terceirizada para uma empresa antiga e estável. Foram observadas uma ou a outra forma de mobilidade; por vezes, as duas se articulam sob formas variadas.

Tendo em mente essas modalidades de mobilidade, diferenciamos dois tipos de trajetórias (e de carreiras): o que chamamos de "feminina" e o que reconhecemos como "masculina". Na literatura dirigida ao tema, mais desenvolvida no campo da chamada "sociologia do emprego", as carreiras femininas se caracterizam, em particular, pela sua natureza entrecortada e truncada, assim como pelas diversas formas (também chamadas) "atípicas" de emprego, por exemplo, o trabalho em tempo parcial. Nessa perspectiva, considera-se como carreiras "femininas" aquelas orientadas por eventos extraprofissionais, notadamente familiares. As "masculinas" estão estruturadas principalmente pelas oportunidades profissionais $e$ escolares que se oferecem no curso do tempo. A partir desse corte

9 Ver Alonzo, 1996; Angeloff, 1999, 2000; Battagliola, 1984; Maruani, 1993, dentre outros. 
A construção social de trajetórias de mando

de gênero, quais são as representações dos homens e mulheres em relação às suas condutas no mercado de trabalho, e qual a influência dessas representações sobre as trajetórias e seus tipos de dinâmica?

\section{As carreiras "femininas"}

As carreiras chamadas de "femininas" - majoritárias no setor de tele-atendimento - caracterizam-se por uma forma de mobilidade ascendente, social e/ou profissional, de natureza truncada e repetitiva, isto é, marcadas por idas e voltas. Do fato de que as denominamos "femininas" não decorre que sejam projetos apenas empreendidos por mulheres; também há homens com esse tipo de carreira, como ilustraremos adiante com o percurso e o discurso de Roberto. ${ }^{10}$ Os casos abarcam indivíduos de origens diversas. Há pessoas provenientes de meios sociais estáveis, ainda que de origem popular ou numa classe média baixa, com casa própria e um forte suporte da família, mobilizada no apoio a seus filhos, especialmente em relação à escolaridade e à inserção no mercado de trabalho (ver o caso de Fabíola). Mas há também pessoas com uma origem social mais baixa, filhos(as) de empregadas domésticas, órfãos, vários deles negros, oriundos(as) da Bahia ou de outros Estados do Nordeste (ver os casos de Rose $e$ de Roberto). Nesses casos, a família de origem não pode assumir um papel de apoio, ao contrário, a necessidade do ingresso precoce no mercado de trabalho, concomitante com os estudos, prejudica-os e os leva a uma escolaridade tardia $e$ entrecortada, geralmente por eventos familiares. Vejamos cada um dos casos.

A trajetória de Rose, supervisora numa central de atendimento, ilustra muito claramente o aspecto truncado dessas carreiras femininas. As passagens pela inatividade são sempre motivadas por eventos familiares (carreira reprodutiva,

\footnotetext{
${ }^{10}$ Todos os nomes doravante referidos são fictícios.
} 
autoconstrução da casa própria, pedido explícito do marido). Bem assim, são os eventos familiares que a levam a retornar ao mercado de trabalho (desemprego do marido, necessidade de renda, etc.). Não obstante, a cada volta consegue uma mobilidade profissional ascendente que rapidamente acaba por levá-la ao nível de chefia intermediária. $\mathrm{O}$ motivo principal que organiza suas decisões e forja a trajetória de Rose é a sua família.

Rose, em 2002, com 39 anos, é supervisora numa empresa terceirizada de tele-atendimento do setor de telecomunicações, situada na região $\mathrm{ABC}$ paulista. Ela tem um contrato CLT. O seu horário de trabalho é de $12 \mathrm{~h} 30$ às $18 \mathrm{~h} 30$, com um salário mensal de cerca de $\mathrm{R} \$ 850,00$. Afiliada ao sindicato de telecomunicações Sintetel, foi eleita para a CIPA. Nasceu em 1963, em Minas, sendo a caçula de seis filhos. Perde os pais em 1973, com 10 anos, e cresce em Roraima, num convento. Em 1980, com 17 anos, vai morar com uma irmã em Diadema, na Região Metropolitana de São Paulo. Trabalha como vendedora e completa o segundo grau numa escola pública noturna no mesmo ano. Em 1981, com 18 anos, ingressa num banco como caixa; no ano seguinte, casa-se com um carteiro. Mora num apartamento de aluguel; nesse mesmo momento, tem lugar o nascimento da primeira filha e o desemprego do marido. Em 1986, com 23 anos, demite-se do banco a pedido do marido, fiscal na Prefeitura. Em 1987, com 24 anos, novo período de desemprego do marido e procura de trabalho. Entra nas Lojas Americanas como supervisora de departamento. Em 1990, com 27 anos, pede demissão novamente em virtude dos horários (tardios) da jornada de trabalho, atendendo novamente pedido do marido (que voltara a obter trabalho, após uma formação de mecânico no Senai). O casal passa a morar na casa da sogra, para economizar. Em 1991, com 28 anos, nascimento da segunda filha. Em 1993, com 30 anos, compra de uma quitinete, onde se instalam. Em 1994, com 30 anos, nascimento da terceira filha. Em 1997, com 34 anos, compra de um terreno em São Bernardo do Campo, autoconstrução da casa própria. Em 1998, com 35 anos, volta a procurar trabalho e 
A construção social de trajetórias de mando

assume ocupações informais (venda de sutiãs, entrevistadora, etc.), formais (corretora numa imobiliária), e até por conta própria. O marido volta a trabalhar, novamente como mecânico, após outro período de desemprego. Em 1999, com 36 anos, começa a trabalhar nos serviços de tele-atendimento, primeiro como temporária, concomitantemente com o trabalho na imobiliária, depois com um contrato CLT. Em 2002, com 39 anos, sua filha mais velha, de 20 anos, começou uma faculdade particular em São Bernardo, cursando Administração.

Fabíola, tendo se tornado mãe solteira muito jovem, aproveita-se de sua origem social mais privilegiada para criar o seu filho. É com uma idade mais elevada, quase 35 anos, que ela começa uma "carreira": ela procura certa estabilidade profissional, volta a estudar e se casa. Nesse contexto, sua nova família se transforma em motivo para voltar a trabalhar, buscando estabilidade profissional, dado o desemprego do marido, e na expectativa de assim poder realizar o sonho da casa própria.

Fabíola, em 2002, com 36 anos, é operadora de teleatendimento em uma empresa terceirizada (CLT), com perspectivas de integração a uma empresa antiga de telecomunicações (participara de um processo seletivo). Salário de cerca de R\$500,00. Nasceu em 1966 em São Bernardo do Campo (Região Metropolitana de São Paulo). O pai era mecânico montador, aposentado, motorista escolar; a mãe, dona-de-casa. $\mathrm{O}$ irmão mais velho nasceu em 1965, e é engenheiro pela Faculdade de Engenharia de São Bernardo. A irmã caçula nasceu em 1980, secretária, com curso universitário de tradutor-intérprete em faculdade particular. Em 1981, com 15 anos, tem o primeiro emprego formal de balconista, e cursa escola pública durante o período noturno. Em 1985, com 19 anos, tranca matrícula no Colégio Técnico "Anchieta" e completa o segundo grau (supletivo) na Escola Estadual "Amadeu Clivério", em São Bernardo. Nascimento do seu filho. Entre 1986 e 1996 (dos 20 aos 30 anos), várias tentativas de estudar (tenta ingressar na USP, num curso de direito em instituição privada em São Bernardo do Campo) e de 
empregos subalternos na área médica (recepcionista de clínica, assistência médica, etc.) e de venda de anúncios. Em 1996, com 30 anos, encontra um emprego fixo (CLT) em uma agência imobiliária, como corretora de locação. Em 1998, com 32 anos, pede novamente demissão, para cuidar do avô doente no Espírito Santos durante nove meses. Em 1999, com 33 anos, volta para São Paulo com o filho e entra na área de tele-atendimento. Em 2000, com 34 anos, após cinco empregos precários consecutivos, obtidos através de agências de trabalho temporário, encontra um emprego permanente (CLT) em uma empresa de teleatendimento, terceirizada, do setor de telecomunicações em São Bernardo do Campo. É também o ano do casamento: o marido é técnico em eletrônica. Instala-se em apartamento alugado com o marido. Em 2001, ocorre um período de desemprego de oito meses do marido. Em 2002, com 36 anos, ingressa numa instituição de ensino superior privada, em São Bernardo do Campo, no curso de línguas estrangeiras (Licenciatura) $e$ novamente se prepara para o vestibular da USP. Participa de um processo seletivo para trabalhar em uma empresa antiga e estável de telecomunicações. Filho (17 anos) faz curso particular de mecatrônica.

O caso de Roberto é particularmente interessante, na medida em que ilustra a possibilidade de um homem vir a construir ao menos temporariamente uma trajetória de tipo "feminina", isto é, onde as micro-decisões que a conformam são fortemente orientadas por motivos familiares. De uma origem social muito baixa, filho de uma empregada doméstica oriunda da Bahia, ele chegou ao nível de gerência, após o que ficou desempregado. De volta à ativa, prefere aceitar um emprego cujos horários de trabalho (de apenas seis horas por dia) lhe permitiam assumir as suas responsabilidades familiares e cuidar de sua filha pequena.

Roberto, em 2002, com 28 anos, é operador de teleatendimento em uma agência de emprego sindical, mantida em parceria com a Prefeitura, situada na região do $\mathrm{ABC}$ paulista 
A construção social de trajetórias de mando

(contrato CLT). Ele tem um salário de cerca de $\mathrm{R} \$ 700,00$ e uma boa estabilidade no emprego, com perspectivas de promoção profissional na Prefeitura. Nasceu em São Paulo. Mãe empregada doméstica residente no emprego. Até os 10 anos, em 1984, foi criado por amigos da mãe, em Minas (Três Corações). Em 1988, com 14 anos, entra no mercado de trabalho (balconista em lojas de tecido do centro de São Paulo, office-boy), ao mesmo tempo em que faz seus estudos numa escola pública. Casamento da mãe e compra de uma casa pelo padrasto, no Ipiranga. Em 1991, com 17 anos, completa o segundo grau e trabalha numa metalúrgica (controle de qualidade) no bairro do Ipiranga. Em 1992, após um ano $e$ oito meses, pede demissão (num conflito com o chefe) $e$ volta a trabalhar nas lojas de tecido do centro. Em 1994/95, como autônomo, monta um pequeno bar. A experiência não deu certo $e$ ele vende o local. Em 1995, com 21 anos, começa uma carreira na praça da alimentação do shopping Morumbi; iniciando como ajudante de cozinha, chegou a ser encarregado em 1997. Nesse ano, com 23 anos, muda para outro shopping, na região do $A B C$, e entra numa rede de restaurantes. Em 1998, com 24 anos, nascimento de sua filha. Em 1999, com 25 anos, após ter chegado ao nível de gerência (treinador) no shopping na região do $A B C$, tem período de desemprego e separação de sua namorada (moravam juntos em Santo André). No mesmo ano, ingressa no serviço de atendimento ao público da agência de emprego (recrutado através da Prefeitura, onde entregara um curriculum), $e$ volta a morar com a mãe. Recebe promoção para o serviço de captação de vagas por telefone; trabalha seis horas por dia (à tarde) para tomar conta da filha no período da manhã (à tarde, a prima toma conta da filha).

Como a nossa interpretação sobre esses trajetos pode ser iluminada pela observação da maneira como deles falam os sujeitos que os fizeram? Vejamos em seguida.

A análise do discurso de Rose - uma carreira "feminina" mostra, de um lado, a interiorização de um trabalho "feminino", como parece ser nos serviços de tele-atendimento, atividade que 
lhe facilita fazer face simultaneamente às demandas do papel de "mãe de família" $e$ às exigências do trabalho. Mas mostra também, por outro lado, a permanente e desigual necessidade de negociar os deveres de mãe e de esposa no espaço público.

Rose: (...) em telemarketing é lei essas seis horas [de trabalho]. Aí, dá tranqüilo para cuidar da casa, da roupa, das crianças, dá para mandar tudo mundo para a escola; eu chego em casa, você prepara uma janta. Então, fica uma coisa mais equilibrada. Tá entrando um salário, você está fazendo a sua casa, o marido também hoje está trabalhando.

Rose: (...) aí, aquela cobrança do marido, ele até já tinha arrumado um emprego, lá, na Prefeitura, de fiscal, estava ganhando melhor; aí, pediu para que eu saísse. Aí, eu pedi a conta no Unibanco e saí. (...) Foi ele, eu não queria sair. Por mim, eu teria continuado, feito plano de carreira. Eu gostava, eu adorava, eu adoro trabalhar fora.

Porém, é destacável a maneira pela qual ela se apresenta no espaço público. O discurso sobre si valoriza sempre as suas ações $e$ iniciativas, sublinhando suas próprias competências. Nesse sentido, em Rose, as representações sobre o trabalho assemelhamse àquelas que tipificariam uma perspectiva mais propriamente "masculina", ao contrário do que nos faria crer o conjunto de sua trajetória.

Rose: Nas empresas que eu trabalhei, e fiquei... assim... bastante tempo em todas elas, eu pedi demissão. Em nenhuma eu fui demitida. Em todas elas.

Rose: Eu tive muita facilidade, tenho, pra conversar com o público. Já trabalhei em vários serviços de vendas, entrevistas, sempre com o público.

Rose: Eu sempre fui uma pessoa batalhadora, sempre. Eu gostava de fazer coisas diferentes. 
A construção social de trajetórias de mando

Ao contrário de Rose, as representações de Fabíola em relação ao trabalho correspondem ao que seria considerado uma visão "feminina"; sua carreira é igualmente orientada por eventos familiares. As possibilidades de ascensão social e profissional são valorizadas, mas significativamente elas são representadas como uma oferta, quase uma dádiva da empresa, e não como uma meta individualmente almejada e para cujo alcance a pessoa tenha se esforçado ou esteja se esforçando. Sua identidade primeira se expressa através de sua condição de sexo, que opera como o elemento de mobilização e de mediação das suas representações acerca do mercado de trabalho. Em relação à carreira profissional, o aspecto mais valorizado é a natureza do emprego, isto é, as vantagens sociais a ele vinculadas e as possibilidades e recursos que oferecem para o seu projeto de família.

Fabíola: É um trabalho do qual eu gosto muito porque, eu sou mulher, sou mãe, sou casada, e estudo. Então, eu tenho marido, tenho filho e ainda tenho que estudar $e$ tenho que cuidar da minha casa. Então, eu trabalho meio período. O bom para mulher é isso. (...) Por exemplo, existem grandes possibilidades... por exemplo, eu fui indicada para trabalhar em outro setor, que é o SAC, Serviço de Atendimento ao Cliente. (...) Então, agora o meu marido ficou desempregado oito meses. Por isso te falo, agradeço muito ter esse emprego. Porque com esse salário... porque com nossas economias foi que a gente segurou quando ele esteve desempregado. (...) Faz dois anos que trabalho aqui. Tinha parado um tempo de estudar, fiquei 11 anos sem estudar. Hoje me arrependo muito, porque eu perdi, mas nunca é tarde para estudar.

Roberto, que foi também um dos poucos entrevistados masculinos com uma idade mais elevada e num momento do ciclo de vida em que já havia constituído família, apresenta um discurso híbrido em relação à sua situação de trabalho. De um lado, 
fazendo jus à sua carreira "feminina" truncada (lembre-se o leitor que ele passou de gerente numa rede de restaurantes a operador de tele-atendimento), Roberto representa - e assume - a sua situação atual por referência ao seu contexto familiar de pai divorciado com uma filha pequena.

Roberto: Minha prima é solteira, ela é nova, tem 17 anos. Ela só estuda no período da manhã. No período da manhã, eu estou em casa, eu cuido. Aí, quando eu saio, ela olha. (...)

Embora assumindo o papel de "pai responsável pela filha", Roberto também manifesta uma representação de si que valoriza as suas capacidades de trabalho, de aprendizagem $e$ de promoção, em conformidade com o que seria esperado num desempenho de papel considerado como "masculino".

Roberto: Aí [na rede de restaurantes] eu fui promovido para treinador. Em todos os meus empregos houve uma promoção. Graças a Deus! (...) Porque [eu] era muito esperto para trabalhar, [para] pegar as coisas rápido.

A comparação entre essas três carreiras "femininas", aí compreendida a de um homem, pode ser construída a partir da análise das representações dessas pessoas com relação à sua situação atual de trabalho e à carreira no seu conjunto. $\mathrm{O}$ que se revela nessa comparação? Desde logo, uma importante heterogeneidade nos percursos específicos. Ademais, vemos que o sexo $e$ a origem social não se constituem em determinantes exclusivos que conduzam, por si só, a certo tipo de trajetória. Observamos que uma forma de representação acerca do próprio papel no mercado de trabalho - considerada mais "masculina" parece ser um componente das construções discursivas nas carreiras ascendentes. Tais carreiras, embora entrecortadas em ciclos repetitivos, mostram-se progressivamente associadas a uma mobilidade hierárquica, como ilustra o caso de Rose. E mesmo se 
A construção social de trajetórias de mando

a família (o marido) lhes impõe uma carreira truncada, é a mesma família que pode funcionar como motor de ascensão, como no caso de Fabíola, em que foi o fator a impulsionar a sua mobilidade, ainda que tardia. Assim, curiosamente, entre as mulheres, a familia pode operar tanto como freio quanto como motor de mobilidade, a depender do momento no ciclo de vida, fator que se destaca entre outros - como a escolaridade e a origem social. Nisto nos deteremos, em seguida, ao analisarmos exemplos-tipo de carreiras chamadas "masculinas".

\section{As carreiras "masculinas"}

As pessoas que tipificam essa modalidade de percurso e de representação são, significativamente, mulheres e brancas. Elas têm segundo grau completo ou mesmo, por vezes, terceiro grau (completo ou incompleto), como Rosângela. A possibilidade de acesso a uma universidade pública faz parte do seu horizonte almejado. A carreira é do tipo "masculino" (como se ilustra em seguida com o caso de Rosângela): nela, as micro-decisões são orientadas principalmente por motivos profissionais.

Rosângela beneficia-se de sua condição social para assegurar para si uma promoção social através dos estudos (bolsa de estudos integral resultante de sua atividade como atleta destacada).

Rosângela, em 2002, com 35 anos, foi "coordenadora" (cargo de média chefia) numa empresa terceirizada de teleatendimento no setor de telecomunicações (CLT). Salário de cerca de $\mathrm{R} \$ 2800,00$. Nasceu em 1967, em Santo André (município da região metropolitana de São Paulo). O pai era chefe de manutenção de ferramentaria (aposentado desde 1992), nascido no interior do Estado de São Paulo; a mãe era dona-de-casa, antiga secretária, nascida em São Paulo. Caçula de três irmãs: a primeira, nascida em 1961, era, em 2002, dona de uma empresa de transporte; a segunda, nascida em 1964, era, em 2002, professora de escola primária pública em Diadema (outro 
município da região metropolitana de São Paulo). Em 1985, com 18 anos, termina o segundo grau técnico em processamento de dados, numa instituição particular, o Instituto Pentágono de Ensino de Santo André, com bolsa integral de estudos (obtida dada a qualidade da sua performance como competidora de voleibol). Em 1988, com 21 anos, completa o terceiro grau em Educação Física numa universidade particular de Santo André (bolsa de estudos) e trabalha como professora de primeiro grau num instituto particular e em escolas públicas (não-concursada). Em 1993, com 26 anos, faz vários concursos e é recrutada pela CTBC; começa a trabalhar como atendente em Santo André, promovida a supervisora depois de seis meses. Em 1997, com 30 anos, nova promoção, para "líder", e curso de especialização de quatro meses em marketing, na FAAP, pago pela empresa. Em 1999, com 32 anos, beneficia-se da privatização da empresa e do plano de demissão voluntária. No mesmo ano, casamento (marido é autônomo, escritório de despachante em Santos) e integração a uma empresa terceirizada de telecomunicações (através de um antigo colega), como "coordenadora" da área de atendimento (responsável por cerca de 450 pessoas). Em 2001, com 34 anos, mudança para a casa própria, em Santo André (apt.) e tranca faculdade particular em São Bernardo do Campo, após dois anos e meio (especialização em administração).

Curiosamente, nos discursos das mulheres, como Rosangela, com uma carreira de tipo "masculina" a proatividade não é o traço que mais valorizam quando tratam das suas aquisições no mercado de trabalho.

Rosângela: Quando eu entrei [na CTBC], não pensei em promoção, em alteração, nada disso. As coisas foram acontecendo naturalmente. Não tinha essa coisa na cabeça [de fazer carreira]. Só pensava em trabalhar, em ter um lugar ao sol, fazer um trabalho decente. $\mathrm{E}$ as coisas foram acontecendo naturalmente. 
A construção social de trajetórias de mando

São mulheres que dispõem de uma origem social que lhes permite, em certa medida, escolher o ramo de atuação e conferir prioridade aos estudos; condições que parecem necessárias a que uma mulher venha a construir uma carreira qualificável como "masculina". Entretanto, suas representações sobre a família e o trabalho não precisam (ou não podem) aparecer nas suas construções discursivas como reivindicando para si mesmas, proativa e intencionalmente, essa estratégia.

Entre os homens é certo não ser o sexo biológico o fator que determina o tipo de trajetória. Como ilustrado a propósito de Roberto, uma origem social mais baixa pode não apenas favorecer uma carreira "feminina", como possibilitar um discurso que o deixe livre para assumir essa carreira "feminina".

2.2. Saídas? Percursos de gênero no desemprego, na procura de trabalho $e$ na passagem à inatividade $e^{11}$

$\mathrm{O}$ que aconteceria se nos propuséssemos as mesmas indagações formuladas na parte antecedente, mas agora a propósito de trajetórias de homens e mulheres que, tendo exercido funções de chefia, pequena ou média, estivessem se defrontando com a experiência do desemprego, desafiados a fazer face à saída das posições de mando que antes haviam detido?

Acreditando na capacidade de desvendarmos novos aspectos das carreiras "masculinas" e "femininas", voltaremos nosso olhar para um outro sub-conjunto de casos. Qual é sua especificidade? As entrevistas que trabalharemos doravante foram também colhidas num grupo circunscrito de pessoas, definido por características que as fazem, ao mesmo tempo, partilhar alguns traços e diferenciar-se por outros tantos. Vejamos.

Todos preenchem o requisito básico para o nosso interesse: exerceram, de maneira relativamente duradoura, funções de

${ }^{11}$ A seção 2.2 se apóia numa seleção de casos que foram mais detidamente analisados em Guimarães (2005), bem como em Demazière, Guimarães e Sugita (2006). 
mando, como gerentes ou supervisores; e todos haviam perdido essas funções, estando em busca de trabalho. O requisito de que tivessem chegado a funções de chefia e nelas permanecido por certo tempo produziu outra "natural" homogeneidade: têm mais idade que o grupo de trabalhadores(as) do tele-atendimento, que ainda cumpria um ciclo de mobilidade de entrada nas funções de mando. Por isso mesmo, quase todos já tinham a posição de chefes nos seus domicílios ou eram cônjuges com vários filhos. Mas a diferenciá-los havia pelo menos três características importantes: o sexo, a condição racial e o meio social de origem.

Eles são particularmente interessantes do ponto de vista qualitativo por tratar-se de indivíduos oriundos de meios sociais muito distintos dos que se constituíam em meios de recrutamento para a maioria dos desempregados de São Paulo. Entretanto, tal como veremos logo em seguida, dadas as diferenças de gênero, essa expectativa se mostrou válida apenas no que concerne aos homens gerentes. Isto porque, entre as mulheres, é bastante distinto o significado das funções de pequena e média chefia, em especial, dado o fato de que o seu nicho no gerenciamento se concentrava na supervisão de ocupações socialmente inferiores, via de regra associadas a papéis "femininos" relativos ao "cuidado".

Mas antes de passarmos aos casos escolhidos por sua maior densidade e riqueza discursiva, vale uma observação comparativa preliminar. Doravante trataremos de "carreiras" numa acepção muito especial, dada a circunstancia de que, agora, os indivíduos são todos eles desempregados, privados de uma ocupação que sustente a mobilidade profissional. Nesse sentido, o desemprego opera também como um elemento a premi-los para uma rota de mobilidade social descendente. Sendo assim, por que continuar a tratá-las como "carreiras" (masculinas ou femininas)?

Naturalmente, não se tratará aqui de "carreiras no desemprego". Antes, analisaremos se (e como) o discurso sobre o desemprego se constitui num território onde se pode reconhecer a vigência de um modelo de orientação de conduta pautado pela 
A construção social de trajetórias de mando

força simbólica de uma "carreira" ou, pelo menos, de objetivos profissionais. Do mesmo modo, importará verificar como transcorreu a carreira perdida, truncada pelo desemprego; quais os fatores que, na construção discursiva do entrevistado, haviam dado sentido ao curso da sua trajetória e orientado as suas escolhas, possibilitando o ingresso em posições de poder $e$ explicando a perda destas.

\section{As carreiras "masculinas"}

Uma primeira observação poderia ser antecipada a título comparativo. É apenas entre os homens que se podem reconhecer perspectivas que se associam ao modelo "masculino" antes descrito, tanto com respeito à carreira que acaba de ser truncada, quanto à conduta de procura de trabalho, focalizando-as $e$ interpretando-as de maneira fortemente profissional.

$\mathrm{O}$ que caracteriza a trajetória $e$ as construções discursivas relativas a carreiras "masculinas" dos gerentes desempregados? Antes de tudo, a resistência em reconhecer-se no estado de desemprego. A situação atual é, ao contrário, uma situação de "procura de trabalho", não de qualquer tipo de trabalho, mas de procura de trabalho no âmbito de uma área específica de qualificação, na qual o entrevistado reuniu suficiente experiência profissional anterior.

Tomaremos como caso-tipo para ilustrar o desenvolvimento dessa construção o de Emiliano, antigo gerente na área de logística, função na qual estivera empregado por 15 anos. Ele fora demitido no curso de um processo de fusão de empresas, que se segue à compra, por capitais alemães, do grande fabricante nacional de eletrodomésticos para o qual havia trabalhado.

Emiliano nasce em 1964, em São Paulo. Entre 1977 e 1982, ajuda seu pai que trabalha como feirante e se dedica ao futebol de campo amador em alguns clubes paulistas, entre eles, o Corinthians. Em 1982, sai do Corinthians e entra na Portuguesa onde passa a ser remunerado; continua trabalhando na feira com 
o pai, entra na faculdade e abandona o curso no mesmo ano por falta de condições financeiras, e conhece aquela que será sua primeira esposa. Um ano depois, começa a se dedicar também, como aspirante, ao futebol de salão no time da Portuguesa. Em 1984, consegue, por intermédio de um amigo do futebol, um emprego de controlador de estoque em uma revendedora de aço; abandona o futebol de campo para praticar o futebol de salão como amador. Após um ano de trabalho, Emiliano pede demissão da revendedora, pois a empresa era muito longe da sua casa $e$ inviabilizava sua volta aos estudos universitários, que se concretiza em 1985, quando inicia o curso de Administração de Empresas em uma faculdade particular e começa a trabalhar numa fábrica de eletrodomésticos como auxiliar de administração de materiais, emprego novamente conseguido por intermédio de um conhecido do futebol. Emiliano permanece durante 15 anos nessa empresa, onde recebe uma série de promoções. Em 1986, ele é promovido a analista de estoque, em 1987 a encarregado de administração comercial, em 1989, ano em que se forma no curso de Administração, a encarregado de custos e orçamentos e em 1991 a supervisor de postos autorizados. Após 12 anos de namoro, Emiliano casa-se pela primeira vez em 1993, quando é promovido a supervisor geral de distribuição e logística. O casamento durou apenas dois anos; após cinco meses da separação, Emiliano começa a namorar aquela que será sua segunda esposa; ela trabalhava na mesma empresa que ele, no setor de telemarketing. Em 1996, ele é promovido a gerente de logística; no ano seguinte casa-se pela segunda vez, compra uma casa em Santo André e pede a sua esposa que se demita para cuidar da casa e do filho, que já estavam gestando. Em 1998, nasce o primeiro filho de Emiliano; em 1999, ele compra uma casa para seus pais, que saem do Aricanduva e mudam-se para Santo André, perto do filho. Por pressão de sua esposa, ele consegue para ela um emprego no setor de informática da mesma empresa onde ele era gerente e onde ela já trabalhara. Em junho de 2002, ainda no cargo de gerência, Emiliano é demitido, devido a uma 
A construção social de trajetórias de mando

reestruturação organizacional. Desempregado, ele pede que sua esposa se demita novamente para cuidar da casa. Até o momento, era Emiliano quem sustentava a sua casa assim como a casa de seus pais e a de sua irmã, que estava desempregada; com a demissão, essa ajuda à família se torna impossível. Em outubro de 2002, Emiliano é encontrado por nossa pesquisa em um bairro de classe média alta de Santo André, onde morava com a esposa e o filho. Sua esposa continuava desempregada desde o pedido de demissão da fábrica de eletrodomésticos e encontrava-se grávida do segundo filho. Emiliano também continuava desempregado, após ter recusado algumas propostas de emprego. Ele estava procurando emprego através de contatos pessoais e de agências na internet; fazia também eventuais serviços de consultoria para empresas, entre elas, a do ex-presidente da última empresa em que havia trabalhado. Para sobreviver, contava também com o dinheiro recebido de indenização por sua demissão.

Provocado por nossa primeira pergunta a falar da sua situação atual, ele diz: "meu currículo está lançado na Internet". Responde de maneira significativa, objetivando a sua situação pessoal num curriculum vitae que circula, num mundo virtual, em busca de oportunidade. Ora, haverá algo mais impessoal, maneira mais distante e desencarnada de falar de si e da experiência do desemprego? Pois bem, é dessa forma que Emiliano estabelece o território a partir do qual construirá o seu discurso. Só em seguida fala verdadeiramente de si, para dizer que não tem "trabalho efetivo", e que está buscando "uma vaga efetiva". E o que confere efetividade a um trabalho (ou a uma vaga)? Emiliano logo se encarrega de esclarecer: "estou buscando uma vaga efetiva, no mercado, dentro da minha área, dessa área que eu me especializei".

É somente no curso da entrevista que a palavra "desemprego" espontaneamente aparece. Mas, ainda assim, numa construção que reitera a dificuldade, a recusa mesmo, de se considerar um desempregado, alguém em estado de desemprego. Emiliano dirá: "Eu me desempreguei", uma construção 
gramaticalmente absurda, no português culto, na medida em que confere ao sujeito uma voz ativa na produção de um efeito do qual (no caso deste verbo) ele é necessariamente paciente, nunca agente. E, de fato, Emiliano não "pedira demissão" (forma que seria gramaticalmente adequada), mas "fora demitido"; ou, para usar a palavra-anátema, "fora desempregado".

Ora, como Emiliano constrói seu argumento para dar sentido ativo ("eu me desempreguei") a algo que só tem sentido na voz passiva ("eu fui desempregado")? Duas construções argumentativas são por ele mobilizadas. Em primeiro lugar, a demissão foi inesperada; em segundo lugar, diante da demissão, ele optou, ao menos inicialmente, por só aceitar vagas na sua área de especialização e com certo status profissional. Havia um passado profissional e uma posição a preservar; um e outro eram centrais à sua identidade como pessoa e, nesse sentido, serão reiterados ao longo de toda a entrevista.

Emiliano: A gente não esperava $e$ acabou pintando essa demissão inesperada. Eu optei, vamos dizer assim, porque não conseguia trabalho na minha área, dentro da minha área que é logística; fui gerente de logística algum tempo e... (...) eu não conseguia dentro dessa posição de gerência (grifos nossos).

E é somente quando fala enquanto um gerente, enquanto alguém que teve o poder de demitir, que Emiliano se permite tratar a si próprio como alguém que "foi demitido"; mas, ainda assim, rapidamente retoma seu tom de chefe. Diz ele:

Emiliano: (...) demitir é uma coisa terrível. Ser demitido também [risos]. Eu nunca tinha sido, né? Mas demitir... nossa! Demitir é terrível. É legal quando o cara dá motivo, aí você chama e fala (...) (grifos nossos).

Vários elementos se destacam na sua maneira de construir o argumento contra o "estado de desempregado", por ele recusado. 
A construção social de trajetórias de mando

Emiliano nos apresenta a situação transitória e inesperada da demissão. E, mesmo assim, esta é anunciada num modo tal que fica claro não se tratar da demissão de "um qualquer", mas de alguém que antes tivera o poder de demitir, um gerente!

E como descreve sua situação atual vis-à-vis o mercado de trabalho? Ou, dito mais claramente, o que Emiliano queria nos sinalizar sobre sua situação atual ao dizer, no início de seu discurso, que estava em busca de um "trabalho efetivo", de uma "vaga efetiva"?

Emiliano: E eu me posiciono assim, eu tenho feito alguns trabalhos de consultoria. Mas na realidade não é isso que eu quero porque mês eu tenho alguma coisa, mês eu não tenho nada e eu tenho minha família pra tocar e agora com essa gravidez inesperada... Porque a minha indenização, tudo eu recebi já tá indo embora; tá indo embora... Porque não dá, o que eu ganho não dá pro meu..., pro gasto que eu tenho. Os poucos trabalhos que eu tenho feito, né, não dá... (grifos nossos).

Não sem razão. Emiliano tinha que se manter e manter sozinho a sua família, posto que obrigara sua esposa a pedir demissão. Tal como nos conta, uma vez desempregado, não admitia fazer o trabalho doméstico e muito menos vê-la sair cotidianamente para trabalhar na mesma empresa que $\mathrm{o}$ despedira; melhor que ela pedisse demissão, que cuidasse da casa, e ele sairia em busca de um novo trabalho.

Inicialmente lançou mão da indenização recebida em decorrência da demissão; posteriormente, como não aparecia uma vaga no seu campo, passou a viver de pequenas consultorias que lhe eram encomendadas pelo antigo presidente da empresa em que trabalhara, o qual era agora um empresário independente, tendo montado uma firma própria. Para ele, esse não era um "trabalho efetivo", dada a irregularidade da atividade e o risco da descontinuidade dos rendimentos. 
É apenas no final da entrevista que a condição de desempregado aparece referida como um fado. Mas, novamente, numa construção discursiva que o distingue do desempregado qualquer. Depois de haver descrito os sucessivos trabalhos de consultoria e os elogios recebidos do contratante, diz:

Emiliano: Quando ele [referindo-se ao antigo presidente] mandou o e-mail pros caras [referindo-se aos que haviam contratado o serviço a ambos], ele escreveu "mestre em logística": "Olha o trabalho do nosso mestre em logística!" Eu conversei com a minha esposa: "É, mestre em logística desempregado!" [risos]. Mal sabem os caras! Putz, meu, não é possível que não pinte uma oportunidade! (Grifos nossos).

Quais elementos podem, então, tipificar essa situação que apresentamos como uma primeira forma-tipo de construção discursiva sobre a experiência vivida e que a conduta atual ela orienta? Essa é uma construção pautada pela identidade proveniente de uma especialização, construída ao longo de um passado profissional; $e$, nesse sentido, a realização pessoal depende do alcance desse objetivo profissional. Embora não tendo trabalho, é ainda nesse território profissional (de conhecimentos, saberes, mas também de relações) que encontra as alternativas de sobrevida, mesmo se instáveis. Apesar de seu insucesso, flagrante na ausência de trabalho regular - e conquanto angustiado -, ele se mantém ativo e acreditando que superará as dificuldades.

O trajeto e a identidade "masculina" são evidentes. A carreira é profissionalmente orientada, a procura de trabalho idem; e, mesmo diante do desemprego, não consegue conviver com a possibilidade de desempenho de outro papel que não o do chefe-provedor; não se permite ser sustentado pela mulher $e$ cumprir papéis reprodutivos, no âmbito familiar: obriga-a a demitir-se, mesmo se com isto os dois provedores agora se encontrem sem ocupação regular. 
A construção social de trajetórias de mando

Certamente poderíamos ser levados a explicar as características dessa situação-tipo e as tensões nela envolvidas a partir da natureza da trajetória anterior no mercado de trabalho. Vale dizer, esse tipo de construção discursiva seria visto como tanto mais provável quanto mais próximos os indivíduos estivessem de um tipo de percurso prévio ao desemprego que pudesse ser descrito (i) pelo caráter contínuo da trajetória ocupacional anterior, (ii) pela recorrência de empregos duradouros, (iii) com desligamentos (via de regra) negociados $e$ (iv) episódios curtos de desemprego. Assim, essa seria a maneira de viver o desemprego característica dos que tiveram um percurso estável e virtuoso para os termos brasileiros. Tal percurso teria sido posto em cheque por uma demissão que surpreende o indivíduo $e$ que, para sua má-sorte, ocorre num contexto de crise no mercado de trabalho (como o dos anos 90). Disso resulta a experiência de uma privação duradoura de emprego, mas que acaba por desembocar na obtenção de um novo trabalho, ao menos similar ao almejado. ${ }^{12}$

Embora o argumento anterior pareça plausível, a realidade (tal como vivida e representada discursivamente pelos indivíduos) é, entretanto, um pouco mais complexa. O caso-tipo subseqüente ilustra uma variante desse caminho, e é elucidativo na medida em que mostra como trajetórias prévias similares não são suficientes para explicar as escolhas no mercado de trabalho e as construções discursivas mobilizadas pelos indivíduos para exprimi-las. Tomaremos os exemplos de Hildegardo e Jônatas para, ainda que de maneira bem mais breve, mostrar como as significações conferidas e os mecanismos mobilizados podem diferenciar percursos cuja inscrição estrutural é semelhante.

Vários pontos parecem fazer convergir esses novos casos e o anterior. Todos refletem percursos de mobilidade sócio-familiar ascendente de indivíduos que tiveram trajetórias regulares no

${ }^{12} \mathrm{E}$, de fato, esse foi o desfecho do caso de Emiliano, quando o reencontramos 18 meses depois. 
mercado de trabalho. Em termos subjetivos, em todos os casos existe uma forte internalização do papel de provedor (se casado) ou da responsabilidade do auto-sustento (se solteiro). E em todos os casos os indivíduos foram lançados de volta à procura de trabalho num momento de crise econômica.

Há, contudo, uma especificidade nos casos de Hildegardo e Jônatas, quando comparados ao de Emiliano: os dois primeiros tiveram que fazer face aos desafios de seus projetos pessoais, que acabaram por acarretar a perda do trabalho. Que desafios foram estes? No caso de Hildegardo tratava-se de "viver com qualidade", isto é, de gerir sua relação com o trabalho profissional de maneira a aproveitar a vida em São Paulo, cidade para onde migrara, deixando o Estado de Mato Grosso, encantado com as oportunidades culturais e de lazer da grande metrópole. No caso de Jônatas, tratava-se de gerir sua depressão, que se segue à morte da mãe; para tanto, deixou o trabalho, viajou por alguns meses; de volta, e mesmo com a compreensão do superior imediato, Jônatas não mais se sentia à vontade na firma, uma vez que outra pessoa havia assumido a sua função de chefia intermediária. Tanto Hildegardo como Jônatas exprimem a força dos projetos que emergem dos constrangimentos de suas próprias vidas pessoais e de suas próprias decisões individuais.

Entretanto, o trabalho profissional permanece importante para ambos, continuando a dotar de sentido as iniciativas de procura de um novo emprego. Mas é também verdade que, durante um momento, o significado subjetivo do trabalho profissional parece sobredeterminado pela força dos projetos pessoais e das novas necessidades emocionais, embora sua importância, no longo prazo, jamais tenha estado em risco. São os constrangimentos pessoais que dão a chave para que se explique a significação subjetiva da perda de trabalho. Eles afastam o desemprego enquanto um destino ou fado, dando sentido à situação atual de privação de trabalho. A duração dessa privação é argumentada antes como efeito da conjuntura que de seus perfis pessoais, já que ambos se crêem bem colocados em termos da 
A construção social de trajetórias de mando

pertinência dos seus objetivos face ao passado profissional. Por isso mesmo, não precisam recorrer a "palavras especiais" ou a eufemismos neologistas, como Emiliano ("eu me desempreguei") para falar do desemprego. Ele é tido como uma conseqüência prevista de um projeto pessoal, que ocorre numa circunstância fortuita: uma conjuntura do mercado pouco favorável. Enfim, eles se reconhecem numa "situação" de desemprego e não se sentem como desempregados duradouros.

No dizer de Hildegardo, respondendo à pergunta sobre a sua situação atual de trabalho:

Hildegardo: Boa não está. Primeiro que eu fiquei desempregado sete meses, ai fui parar em outro setor $e$ ganhando metade do que eu ganhava. Sendo que por dois ou três meses foi de propósito, né ...nos primeiros três meses eu falei que ia dar uma descansada ...e eu queria uma qualidade de vida melhor; eu tava buscando isso. Só que ai eu percebi que tava, que era incompatível o mercado de trabalho com relação ao que eu queria. Que não dava... (grifos nossos).

Ou, no dizer de Jônatas, também respondendo à mesma pergunta:

Jônatas: Fiquei desempregado aproximadamente dois anos. E o desemprego ainda está em todo país, ele ainda existe. Mas, graças a Deus, eu saí, estou agora livre. Estou trabalhando. Foi uma fase difícil, realmente. Agora, eu estou me reerguendo. Me estruturando novamente... (grifos nossos).

Enfim, dois elementos parecem chaves nessa construção discursiva: a existência de um projeto pessoal que explica o estado atual de desemprego e a busca sistemática de trabalho para dele sair, acreditando na capacidade profissional como propiciadora. 


\section{As carreiras "femininas"}

Haveria uma maneira "feminina" de representar a experiência vivida no trabalho de chefia, bem como a perda de um status e a passagem pelo desemprego? Certamente sim. "Feminina" no sentido que a literatura confere a esse modelo, porque fortemente pautada pelos constrangimentos e significações construídos a partir da esfera privada, da vida familiar, e assentados nas obrigações socialmente estruturadas ao redor dos papéis de gênero.

Três casos densos foram escolhidos para ilustrar trajetos, significados e mecanismos passíveis de dar sentido ao trajeto e ao discurso: Astrud, Nara e Maria. São deliberadamente distintos em termos sociais. Assim como fizemos para as carreiras "masculinas", tomaremos um desses casos como referência e apresentaremos os demais em diálogo com o mesmo. Astrud será o nosso caso carro-chefe.

Astrud nasceu em 1962, na cidade de São Bernardo do Campo, onde reside com um dos filhos e seu companheiro. Em 1976 iniciou o curso de magistério, que concluiu em 1980. Em 1981, casa-se com seu primeiro marido e alugam uma casa em São Bernardo do Campo. Neste mesmo ano, Astrud cursava o primeiro ano no ensino superior, do curso de Letras, que abandona um ano depois por estar casada e grávida. Aos 20 anos, Astrud tem seu primeiro filho e logo após o nascimento da criança consegue, por intermédio de uma amiga, um emprego em uma casa de tintas, como auxiliar de escritório. Trabalhou nesse local por aproximadamente quatro meses, até que se viu obrigada a abandonar o emprego devido às pressões do marido. Em 1983 muda-se para Santos, pois seu marido conseguira um emprego nesta cidade como serralheiro. Em Santos, Astrud trabalha alguns poucos meses como empregada doméstica, até que, em 1985, resolve voltar a São Bernardo com seu filho e alugar uma casa. Seu marido, desempregado, retorna a São Bernardo meses depois e vai trabalhar com o pai de Astrud, como motorista de ferro 
velho. Ainda em 1985, ela começa dar aulas em uma escola particular, com registro em carteira. Com vistas a aumentar a renda mensal, Astrud consegue mais um emprego, em uma loja, aproveitando os meses que antecedem as festas de final de ano. No entanto, fica na loja apenas por um mês, pois não consegue conciliar os dois empregos com os "afazeres do lar": cuidar da casa, do bebê, sendo pressionada pelo marido a sair. Em 1986, o pai de Astrud lhe dá a casa em que passa a residir até o momento em que a encontramos. Nesse mesmo ano, ela deixa o emprego da escola por causa do nascimento do segundo filho, acontecido em dezembro. Em 1988, nasce o terceiro filho e Astrud continua fora do mercado de trabalho. Em setembro de 1989, Astrud separa-se do seu primeiro marido que a continuaria mantendo $e$ aos filhos até que ela conseguisse arrumar um emprego, fato que ocorre nesse mesmo ano, quando Astrud, por indicação de uma amiga, vai trabalhar em uma corretora de seguros, fazendo serviço de contínuo, recebendo um salário mínimo. Nesse momento, Astrud decide alugar a parte da frente de sua casa para ajudar no orçamento mensal. Em 1990, ela sai da corretora de seguros para trabalhar em uma creche, indicada por sua prima, como professora. Ao mesmo tempo, volta a estudar, iniciando o curso de pedagogia em uma faculdade particular, abandona, novamente, meses depois, por não conseguir pagar a mensalidade. Em 1991, Astrud deixa o emprego da creche para entrar em outra, por indicação da mesma prima, mas agora como coordenadora pedagógica; no entanto, permanece apenas alguns meses na ocupação. Nesse mesmo ano, diante do agravamento das suas dificuldades financeiras, Astrud trabalha com os irmãos no ferro velho do pai, como sucateira. Em 1994, Astrud não pode mais alugar a parte da frente da sua casa, pois o imóvel estava precisando de reforma. Em 1995, arruma um emprego numa padaria. Entra como balconista, depois passa a auxiliar administrativa e, por fim, é promovida a gerente do estabelecimento. Durante o período em que trabalhou nessa padaria, de 1995 a 1997, o estabelecimento mudou de proprietário 
em três ocasiões, mas ela permaneceu empregada como gerente. Em 1997, Astrud trabalha em uma outra padaria, em Santo André, a convite de um dos antigos proprietários da padaria onde trabalhava, novamente como gerente, porém sem registro em carteira. Só será registrada em 1999. Em março de 2000, a padaria abre falência e Astrud é mandada embora. Nesse momento, ela não consegue mais pagar a prestação do carro que havia comprado e seu irmão o faz. Também não consegue pagar o convênio de saúde e passa a recorrer ao SUS. Ainda nesse mesmo período, passa a fazer diversos trabalhos artesanais para sobreviver - crochê, biscuit, cesta de café da manhã e telemensagens.

A sua biografia ocupacional é exemplar, dadas as expectativas de uma trajetória "feminina": truncada, entrecortada por eventos da vida familiar, numa sucessão de idas e vindas no mercado de trabalho, facilmente datadas pelos casamentos e pela carreira reprodutiva. $\mathrm{O}$ exercício da função de gerente num mesmo estabelecimento, sob três diferentes proprietários, bem como em duas diferentes padarias, por indicação dos seus donos, nem de longe deixa em Astrud marcas de uma identidade como "chefe", ou mesmo um sentido de formação ou de aptidão profissionais, que marque sua narrativa sobre o seu percurso no trabalho ou suas iniciativas para saída do atual desemprego. A gestão das lanchonetes, mesmo na primeira delas onde progride de balconista a gerente, jamais aparece relatada como uma evidencia de mobilidade profissional ou mesmo como um ativo a partir do qual construa um orgulho profissional. Ao contrário, sua imagem de mãe "batalhadora", de provedora a qualquer custo da sobrevivência dos filhos, é a constante no seu discurso.

Asrtrud: Eu tenho três filhos, eu sou separada, eu tenho três filhos. Faz pouco tempo que eu moro com esse rapaz e ele também não tem emprego; ele faz bico de laqueação. Então, eu tenho que me virar de alguma maneira, porque 
A construção social de trajetórias de mando

eu tenho ainda duas crianças ainda de menor, que estudam e tudo.

E emprego, faz um ano, quer ver, foi em março que eu fui mandada embora, eu era gerente numa padaria, aí em março, um ano e... deixa eu ver [conta nos dedos os meses desde então] março, abril, maio, junho, julho, agosto, setembro, outubro, novembro, vai fazer um ano e nove meses que eu estou desempregada.

De vez em quando, eu entro em depressão e não saio de casa, não procuro. Porque você vai num lugar, que você tem certeza que você tem, que você pode trabalhar, que você vai conseguir, só que eles te negam a vaga. Aí eu volto pra casa derrotada, chorando, dizendo "eu nunca mais vou procurar, seja o que Deus quiser". Junto latinha, faço tele-mensagem, pra minhas coisinhas, pra mim comprar minhas coisas, pra mim fazer e vou levando. (...) E aí situação é essa, eu acho que é a situação do Brasil, não é só a minha.

E se veleidades quanto a aptidões existiram, elas formam parte de uma narrativa sobre um passado remoto, quando almejara fazer "um curso de jornalismo", como diz, opção indesejada pelos pais (que a queriam professora) e, segundo ela própria, incompatível com o estatuto de "mulher casada", que cedo alcançaria. Astrud, quando encontrada por nosso trabalho de campo, fazia tele-mensagens, recolhia latinhas pela rua com os filhos para revendê-las, e articulava toda sorte de expedientes para prover renda, perfeitamente esquecida de que já fora uma gerente, e tão despossuída da sua identidade de gestora de empreendimentos que até mesmo o seu trabalho de organização das cobranças no negócio do seu atual marido (em que estava permanentemente envolvida), desaparecia do seu discurso sobre a vida cotidiana e somente veio à tona na segunda entrevista, um ano depois do seu primeiro (e longo) relato biográfico.

A ausência de horizontes, fora da "viração" cotidiana, com seu trabalho desqualificado e escassamente remunerado, também 
aparece de maneira emblemática na trajetória e no discurso de Maria.

Maria nasceu em 1948 na cidade de Araçatuba em São Paulo. Mãe de cinco filhas, uma já falecida, é casada e tem uma neta, que cria e que a chama de mãe. Tem apenas a $4^{\text {a }}$ série do ensino fundamental. Mora atualmente com a neta em São Paulo no bairro do Jaraguá em um apartamento de propriedade de uma de suas filhas, que obteve o imóvel por meio de um programa governamental de habitação. Em 1980, Maria começou a trabalhar em uma casa de família como diarista e sem registro em carteira. Trabalhou ali por 11 anos, até que, devido à morte de sua filha mais velha, que deixara uma filha de seis anos, Maria e seu esposo resolvem mudar-se para São Paulo, onde já residiam suas outras filhas. Para tanto, seu esposo, que era motorista de uma empresa de transporte coletivo, negociou uma transferência para trabalhar em São Paulo. Em 1991, Maria, seu esposo e a neta fixam residência no bairro da Bela Vista, em Osasco, cidade dormitório da região metropolitana de São Paulo. No ano seguinte, mudam-se para Barra Funda, bairro localizado na cidade de São Paulo, e moram numa casa cedida pelos patrões do marido de Maria. Já instalados, Maria reinicia sua trajetória de trabalho como empregada doméstica diarista, atividade que a ocupa até o ano de 1998. Neste ano, com a aposentadoria do seu marido, eles tiveram que deixar a casa onde viviam e mudar para a Vila dos Remédios, bairro relativamente distante da Barra Funda. Somente em 2000, aos 52 anos, Maria obteve seu primeiro emprego registrado. Indicada por seu genro, Maria trabalhou como "encarregada" em uma empresa de serviços terceirizados de limpeza, localizada em Osasco. Após 11 meses, Maria perde o emprego de encarregada de limpeza porque a empresa desativou o setor. Assim, em 2001, procura outro emprego, sem obter êxito, voltando a fazer faxinas, agora para duas de suas filhas e também para a amiga de uma delas. Ao mesmo tempo, o marido de Maria é internado em uma clínica de repouso, paga com a sua aposentadoria, devido ao alcoolismo e à depressão que se 
A construção social de trajetórias de mando

agravaram com sua passagem à inatividade. Ainda em 2001, Maria e sua neta voltam a morar em Osasco, numa edícula nos fundos da casa alugada por uma de suas filhas. Em dezembro de 2001, na primeira visita da nossa equipe, Maria estava desempregada, procurando emprego; além disso, fazia faxina. Morava em Osasco e aguardava a entrega de um apartamento concedido por um programa de habitação popular. Nele, nós a encontramos quando da segunda entrevista, aproximadamente um ano depois.

A experiência de encarregada do comando de equipes de limpeza em apartamentos de edifícios recém-concluídos, para entrega aos seus primeiros moradores, sua única função de chefia lhe caíra no colo com a mesma extemporaneidade como desaparecera; pela indicação de um parente torna-se chefe, no curso de uma vida dedicada ao serviço doméstico como diarista. No momento em que a crise suprime postos e Maria se vê privada da função de encarregada, seu destino possível não é outro senão o do trabalho doméstico remunerado, mundo do qual viera e para o qual retorna.

Maria: Estou sem trabalhar, estou sem trabalhar. Estou procurando, estou procurando. Mas não é fácil, porque, por causa da idade e também por causa do estudo; o meu estudo é muito pouco.

A gente fica muito triste com isso; até porque você sente, assim, um pouco desorientada, né? Porque até um ano atrás, eu trabalhava registrada numa empresa, era encarregada de limpeza, era encarregada de limpeza! Aí quando foi no começo do ano, eles me dispensaram $e$ aí daí pra cá, às vezes a gente faz um bico, às vezes a gente não faz nada (grifos nossos).

O leitor haveria de argumentar que a origem social de Maria atuaria como um fator determinante da extemporaneidade da sua experiência de mando e de seu destino atrelado ao trabalho doméstico. Mas que dizer de Astrud, gerente por tempo 
considerável $e$ que sonhara $e$ perseguira um diploma universitário? De onde vem a semelhança na resistência em reconhecer-se "chefe"?

Finalmente Nair, tão pouco escolarizada quanto Maria, mas tão mobilizada para o trabalho no espaço público como Astrud, revela, na narrativa da sua trajetória, a mesma biografia ocupacional fragmentada, premida pelas obrigações "de mulher": os maridos que a retiram dos empregos, por desnecessários; a filha que engravida; o pai que adoece. Todos são motivos para sustar e reconverter trajetos, mesmo em momentos aparentemente ascendentes no percurso profissional, cujo ápice fora, como Maria, a função de "encarregada geral" de serviços de limpeza especializada, no seu caso, em estabelecimentos de saúde.

Aproximando essas três mulheres parece estar o fantasma do insulamento familiar que as aprisiona no mundo privado $e$, por assim dizer, apaga os referentes de um passado profissional, tornado longínquo. Este, quando reaparece, tem mais propriamente a forma de uma esperança que de um alvo capaz de organizar a conduta de procura no mercado de trabalho, como no caso descrito dos homens que haviam desempenhado funções de chefia.

No entanto, é possível, como no caso dos operadores de tele-atendimento, reconhecer no discurso de algum homem representações sobre percursos e condutas que os aproximassem daquelas tipificadas como "femininas"? Talvez em Vinicius, um antigo gerente comercial numa locadora de veículos e assessor de diretoria numa agência de viagens, que passa a viver dos ganhos ocasionais de uma função que era antes tida como um divertimento, a arbitragem de futebol. Perseguido pelo desemprego duradouro, a narrativa de seu cotidiano remete a um insulamento familiar e à dependência face a chefes provedores no domicílio (no caso, seus pais aposentados) que se assemelha às narrativas "femininas". Como as mulheres, ele busca qualquer coisa, "independente do que seja": 
A construção social de trajetórias de mando

Vinicius: O que eu quero é me engajar em algum local, trabalhar, quero recomeçar, que tá deixando... eu estou deixando de ter minhas coisas, perdendo algumas coisas, deixando de, me desfazendo de algumas coisas para me manter, né? Que nem, os meus pais com 74 [es]tão aposentados. Muita coisa eu ainda dependo deles ainda, independente de... Lógico que tem a casa aqui com eles, moro com eles, e tudo mais. Mas, no fundo, a gente tem a nossa vida, né? Eu quero é voltar, é retornar; independente do que seja.

Pensando conclusivamente sobre esse último grupo de casos, postados na porta de saída do mundo dos empregos de chefia, o que poderíamos inferir? Alguns aspectos nos parecem particularmente importantes. Primeiro: quando analisamos os relatos das mulheres que ocuparam funções de mando e que hoje estão desempregadas, deparamo-nos com trajetórias que apontam para experiências de trabalho como chefes que, mesmo na base da hierarquia, foram, na maior parte das vezes, excepcionais (quando não únicas) nas suas trajetórias. Entre elas não há itinerário profissional, nem carreira profissional enquanto gerentes; há episódios de trabalho em funções hierárquicas de pequena chefia.

Mais ainda, e este nos parece um segundo aspecto de relevo: quando atentamos para o tipo de atividade que desempenhavam e o tipo de serviço que coordenavam e/ou supervisionavam, vemos que os mesmos não se diferenciavam das atividades constantes da pauta do serviço doméstico: nossas "chefes", com alguma freqüência, lideravam equipes de trabalhadoras contratadas para serviços de limpeza, por exemplo (de apartamentos recém-construídos antes da entrega, de hospitais). Uma vez perdida essa função de chefia, voltam (ou caem) naquilo que lhe é similar: o serviço doméstico remunerado. Parece sem dúvida chocante que as transições ocupacionais desloquem as mulheres "chefes" das empresas de serviço para o cuidado de domicílios, seja no trabalho remunerado "do lar", seja 
no serviço doméstico remunerado "por patroas" ou por membros da família que as apóiam no provimento de renda.

Não sem razão (terceira observação conclusiva) o insulamento familiar parece caracterizar essas mulheres "chefes". Nada disso surge nos achados sobre o percurso e os discursos colhidos junto a homens que tiveram posições de pequenas $e$ médias chefias. Neles, uma identidade profissional está fortemente presente: são "gerentes de vendas", "pessoas da logística", "supervisores no ramo dos transportes", e assim por diante. Se suas trajetórias mostram-se truncadas entre múltiplos eventos profissionais, elas refletem uma "durável sucessão de empregos", na sua quase totalidade obtidos (ou buscados) num mesmo território do mercado de trabalho, no qual se refletem as expectativas de exercício profissional e no qual se exprimem as identidades profissionais assumidas.

Por certo há uma relativa diversidade de origem social entre os casos dos homens "chefes" entrevistados. Entretanto, todos eles provêm de meios sociais de mais alta renda, se comparados às mulheres "chefes". Isso se reflete na forma como discorrem sobre o emprego, a ruptura de vínculos e a procura de trabalho. Assim, é freqüente entre eles um discurso que acentua de modo enfático a satisfação propiciada pelo trabalho, a qualidade de vida no trabalho, a qualidade de vida extra-trabalho propiciada pelo emprego exercido, cogitações inexistentes no universo discursivo das mulheres "chefes". Para os homens, tal satisfação chega a ser um critério para permanecer ou para romper vínculos.

Os mais jovens aderem completamente às formas modernas de busca de trabalho, notadamente via Internet, como mecanismos para localização de oportunidades, difusão de CV's, ou adesão a empresas de recrutamento virtual. Bem assim, trabalhos ocasionais são obtidos e exercidos via contatos por Internet. Isso nem de longe apareceu nos discursos colhidos junto às mulheres "chefes" entrevistadas, aleatoriamente sorteadas no mesmo estoque de casos de onde extraímos os homens. 
A construção social de trajetórias de mando

Finalmente, salta aos olhos uma especificidade na sua representação sobre a perda do trabalho, aí compreendido o próprio desemprego. Entre os gerentes observa-se a tendência a assumir (como seu) o discurso gerencial e de classe de que até bem pouco haviam sido portadores. Há uma lógica compreensível na ação da empresa, mesmo naquela que lhes priva de trabalho. Uma lógica irresistível, mas moderna e por eles decodificável. Dela resulta uma sorte de auto-empreendedorismo, um chamamento à necessidade de se preparar para vender-se enquanto produto num mercado exigente e presidido por uma rationale da qual, ele próprio, até bem pouco tempo, também era parte. ${ }^{13}$

Esses gerentes se diferenciam do grupo dos operadores $e$ operadoras de tele-atendimento, que encontramos em rota de mobilidade ascendente, nas carreiras ou na estrutura social? Por certo que sim. Vários elementos confluem para dar sentido a tais diferenças, vale dizer, ao modo como carreiras "masculinas" $e$ "femininas" são vividas e percebidas por um ou outro grupo. Um desses elementos de diferenciação seria a conjunção entre idade $e$ posição no ciclo de vida; enquanto os operadores e operadoras em mobilidade são, em média, mais jovens e apenas começam a constituir família, os supervisores e gerentes desempregados são predominantemente chefes de família ou cônjuges, com mais idade (idade bem menos competitiva no mercado de trabalho) $e$ acumulando muito mais responsabilidades familiares e encargos reprodutivos. Outro elemento diferenciador é a situação face ao

${ }^{13}$ Seu discurso, nesse sentido, parece ter o tom de um discurso de classe e dista muito daquele recolhido, na mesma pesquisa, entre a maioria dos não-chefes, notadamente entre os operários (homens) entrevistados, para quem o desemprego a que estão sujeitos tem o sentido de algo inexplicável, uma tragédia, uma fatalidade, com laivos de naturalização - aquilo contra o que nada se pode e de onde a auto-culpabilização se mostra a saída explicativa. Não tratamos desses discursos aqui, mas tais achados são extensamente descritos em Guimarães et alii (2003), Guimarães (2005) e Demazière, Guimarães e Sugita (2006). Chamamos a atenção dos mesmos para sublinhar, ainda que em nota de rodapé, a importância da experiência de classe para a compreensão da diversidade dos discursos entre os homens desempregados. 
mercado de trabalho; enquanto os primeiros se movem rompendo as barreiras de entrada, no mercado ou em postos mais altos da carreira em uma nova área em expansão, os últimos saíram das funções de chefia, expulsos pelo movimento de reestruturação, que abre nichos para outros, como o tele-atendimento.

Entretanto, a par de diferenças, encontramos convergências importantes entre destinos e discursos, a principal é a força com que o determinante de gênero parece conferir sentido, distinguindo, os universos discursivos, as experiências laborais e as vivências subjetivas que, por diferentes vias, desafiam-nos a entender a multiplicidade das formas subjetivas de se fazer face ao desemprego. Com isso, pautam tanto as formas de reconhecer-se e ser reconhecido enquanto desempregado(a), como as formas de agir, perseguindo as oportunidades ocupacionais. E é justamente aí que estão os mecanismos pelos quais se forjam, no cotidiano, as mudanças e persistências na estrutura do mercado de trabalho.

\section{Referências bibliográficas}

AlONZO, P. Femmes employees. Paris, L'Harmattan, 1996.

Amadeo, E.; Barros, R.P.; Camargo, J.M.; Pero, V.; Urani, A. Human Resources in the Adjustment Process. Textos para Discussão, no 317 , IPEA, outubro de 1993.

Amadeo, E.; Camargo, J.M.; Gonzaga, C.; BarRos, R.P.; MendonçA, R. A natureza e o funcionamento do mercado de trabalho brasileiro desde 1980. Textos para discussão, no 353, IPEA, outubro de 1994.

ANGELOFF, T. Le travail à temps partiel: un marché de dupes?. Paris, Syros, 2000.

Des miettes d'emploi. Travail, genre et sociétés, $\mathrm{n}^{\circ}$ 1, 1999.

BATTAGLiOlA, F. Employés et employees. Trajectoires professionnelles et familiales. In: KARTCHEVSKY-BULPORT, A. et alii. Le sexe du travail. Paris, PUG, 1984.

BECK, U. The Brave New World of Work. Cambridge, Polity Press, 2000.

BRANDÃO, S. et alii. Mobilidade Ocupacional: A Experiência da Região Metropolitana de São Paulo. In: GuimarÃES, N.A. e HiRATA, H. 
A construção social de trajetórias de mando

Desemprego: Trajetórias, Identidades e Mobilizações. São Paulo, Senac, 2006.

CABANES, R. Travail, famille, mondialisation. Paris, IRD-Karthala, 2002.

CARDOSO, Adalberto. Trabalhar, Verbo Transitivo. Rio de Janeiro, Editora da FGV, 2000.

Comin, Alvaro. Mudanças na estrutura sócio-ocupacional do mercado de trabalho em São Paulo. Tese de Doutorado em Sociologia, Universidade de São Paulo, 2003.

DEDECCA, C. Racionalização Econômica e Trabalho no Capitalismo Avançado. Campinas-SP, Instituto de Economia/Unicamp, Coleção Teses, 1999.

; BRANDÃO, S. Crise, Transformações Estruturais e Mercado de Trabalho. In: APPY, B. et alii. Crise Brasileira: Anos 80 e Governo Collor. São Paulo, CGIL/CUT/DESEP, 1993.

; Montagner, P. Flexibilidade produtiva e das relações de trabalho. Considerações sobre o caso brasileiro. Textos para discussão, no 29, Campinas-SP, Instituto de Economia da Unicamp, outubro de 1993.

DEMAZIÈRE, D. La sociologie du chômage. Paris, La Découverte, 1995.

; DUBAR, C. Analyser les entretiens biographiques: l'exemple des récits d'insertion. Paris, Nathan, 1997.

; GuimarãES, N.A.; SUGITA, K. Unemployment as biographical experience. In: Kase, K. e Sugita, K. (eds.) The Unemployed and Unemployment in an International Perspective: Comparative Studies of Japan, France and Brazil. ISS Research Series, vol. 19. Tokyo, University of Tokyo, Institute of Social Sciences Research, 2006.

DiPRETE, T.A.; KRECKER, M.L. Occupational linkages and job mobility within and across organizations. Research in Social Stratification and Mobility (10), JAI Press Inc., 1991.

ELIAS, P. Restructuring, reskilling and redundancy: a study of the dynamics of UK labour market, 1990-1995. Coventry, Institute for Employment Research, 1997.

ESPING-ANDERSEN, G. Social Foundation of the Post Industrial Economies. Oxford, Oxford University Press, 1999.

FREYSSINET, J. Le chômage. Paris, La Découverte, 1984. 
FRIOT, B. e ROSE, J. La Construction Sociale de l'Emploi en France - Les années soixante à aujourd'hui. Paris, L'Harmattan/ Fórum, 1996.

Gallie, D.; PAUGAM, S. Welfare regimes and the experience of unemployment in Europe. Oxford, Oxford University Press, 2000.

GAUTIÉ, Jerôme. Transitions et trajectoires sur le marché du travail. Quatre-Pages, n ${ }^{\circ}$ 59, Paris, Centre d'Études sur L'Emploi, Sept., 2003.

GEORGES, I. Trabalho e Emprego: Comparação internacional entre trajetórias de atividade feminina (Alemanha, França, Brasil). Relatório Final de Pesquisa (Proc. N. 01/10162-0), FAPESP, São Paulo, 2005.

- Trabalho e emprego: comparação internacional entre trajetórias de atividade feminina (Alemanha, França, Brasil). Comunicação ao XII Congresso Brasileiro de Sociologia, GT Ocupações e Profissões, Belo Horizonte-MG, FAFICH/UFMG, 31 mai-3 jun, 2005 a.

. Trajectoires professionnelles et savoirs scolaires - le cas du télé-marketing au Brésil. Les Cahiers de la Recherche sur l'Éducation et les Savoirs - Dossiê "Formaion et Aprentissage" -, 2005b.

e GUIMARÃES, N.A. Entradas e saídas: diversidades de gênero nas experiências do trabalho e do desemprego entre chefias nos serviços. Anais do $29^{\circ}$ Encontro Anual da ANPOCS, Caxambu, 25 a 29 de outubro de 2005.

GIDDENS, A. The constitution of society. Cambridge, Polity, 1984.

GRÜN, R. Quem é moderno? Um estudo sobre as estratégias discursivas de gerentes brasileiros. Revista Brasileira de Ciências Sociais, ano 7, $n^{\circ} 18,1992$.

. Modelos de empresa, modelos de mundo: sobre algumas características culturais da nova ordem econômica e da resistência a ela. Revista Brasileira de Ciências Sociais, nº 41, 1999.

GuIMARÃES, N.A. Caminhos Cruzados: Estratégias de empresas e trajetórias de trabalhadores. São Paulo, Ed. 34/Programa de PósGraduação em Sociologia da USP, 2004.

Quando a indústria se transforma... atores locais e políticas sub-nacionais de eqüidade de gênero e raça. São Paulo em Perspectiva, vol. 18, $\mathrm{n}^{\circ} 4$, outubro-dezembro, 2004a. 
A construção social de trajetórias de mando

Desemprego: Experiências e representações. Reflexões a partir do caso de São Paulo. Comunicação ao Colóquio Chômage et mobilité professionnelle. Changements institutionnels et trajectoires biographiques. Comparaison Brésil, France, Japon, Paris, 21-22 de fevereiro de 2005. Versão digital em http://www.fflch.usp.br/ sociologia/nadya

O trabalho em transição. Uma comparação entre São Paulo, Paris e Tóquio. Novos Estudos Cebrap, n 76, novembro de 2006.

et alii. Desemprego: Abordagens institucional e biográfica. Uma comparação Brasil, Franca, Japão. Relatório Final do Auxílio CNPq 469792-00, São Paulo, 2003. Versão digital em http://www.fflch.usp.br/sociologia/nadya

e LEITE, M.P. (orgs.) Gestão local, Empregabilidade e Eqüidade de Gênero e Raça: um experimento de política pública na região $\mathrm{ABC}$ paulista. Relatório Final de Pesquisa, FAPESP, São Paulo, 2003. Versão digital em http://www.fflch.usp.br/ sociologia/nadya

HugheS, E.C. Institutional Office and the Person. American Journal of Sociology, 43 (3), 1937.

KNORR-CETINA, K. e Cicourel, A.V. Advances in social theory and methodology, Towards an integration of micro and macro-sociologies. Boston, London and Henley, Routledge and Kegan Paul, 1981.

LAUTIER, B. e MARQUES PEREIRA, J. Réprésentations sociales et constitution du marché du travail. Cahiers des Sciences Humaines, $\mathrm{n}^{\circ}$ 30 (1-2), 1994.

LEDRUT, R. Sociologie du chômage. Paris, PUF, 1966.

MARUANI, M. Les Mécomptes du Chômage. Paris, Bayard, 2003.

e REYNAUD, E. Sociologie de l'emploi. Paris, Éditions La Decouverte, 1993.

Supiot, A. (ed.) Au-delà de l'Emploi. Paris, Flammarion, 1999.

TOPALOV, C. Naissance du chômeur, 1880-1910. Paris, Albin-Michel, 1994.

URANI, A. Crescimento e geração de emprego e renda no Brasil. Lua Nova, n 35, 1995. 